ORNL/CON-306

ENERGY DIVISION

ORNL/CON- -306

DE9 1000051

\title{
BALANCING THE SCALES: DATA ON ELECTRICITY SUPPLY AND DEMAND RESOURCES
}

\author{
ERIC HIRST
}

SEPTEMBER 1990

Sponsored by

Office of Conservation and Renewable Energy

U.S. Department of Energy

Washington, DC 20585
Customer Systems Division

Electric Power Research

Institute

Palo Alto, CA 94303

OAK RIDGE NATIONAL LABORATORY

Oak Ridge, Tennessee 37831

operated by

MARTIN MARIETTA ENERGY SYSTEMS, INC.

Under Contract No. DE-AC05-84OR21400

for the

U.S. DEPARTMENT OF ENERGY 


\section{TABLE OF CONTENTS}

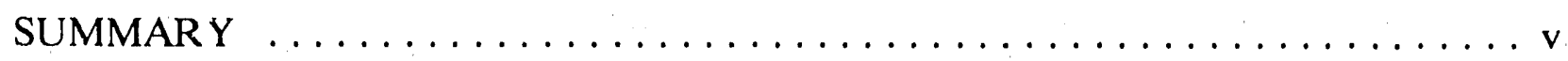

LIST OF ACRONYMS $\ldots \ldots \ldots \ldots \ldots \ldots \ldots \ldots \ldots \ldots \ldots \ldots \ldots \ldots \ldots$

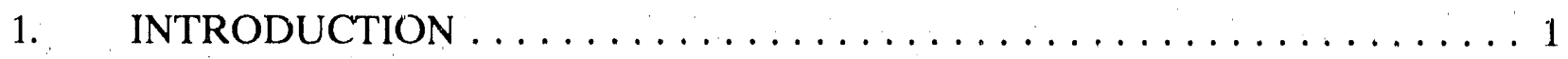

2. DATA ON UTILITY SUPPLY SYSTEMS $\ldots \ldots \ldots \ldots \ldots \ldots \ldots \ldots$

DATA FOR INDIVIDUAL POWER PLANTS $\ldots \ldots \ldots \ldots \ldots \ldots \ldots 3$

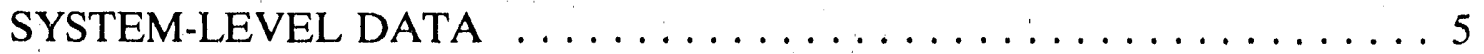

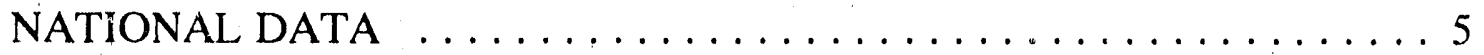

STANDARD DEFINITIONS $\ldots \ldots \ldots \ldots \ldots \ldots \ldots \ldots \ldots$

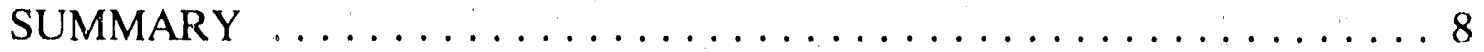

3. KEY CHARACTERISTICS OF UTILITY DSM PROGRAMS $\ldots \ldots \ldots \ldots 11$

4. DSM-PROGRAM PARTICIPATION $\ldots \ldots \ldots \ldots \ldots \ldots \ldots \ldots \ldots \ldots$

PARTICIPATING UNITS $\ldots \ldots \ldots \ldots \ldots \ldots \ldots \ldots \ldots \ldots \ldots \ldots \ldots$

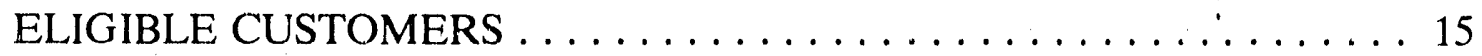

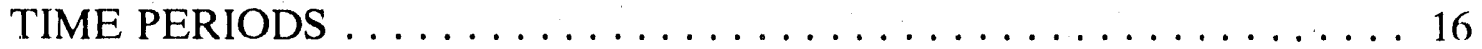

RETROFIT VERSUS REPLACEMENT MARKETS $\ldots \ldots \ldots \ldots \ldots \ldots 16$

NEED FOR STANDARD DEFINITIONS $\ldots \ldots \ldots \ldots \ldots \ldots \ldots$

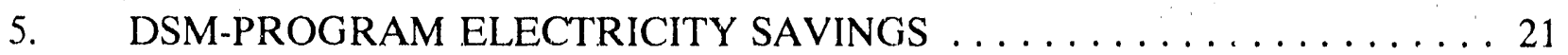

NET VERSUS TOTAL SAVINGS $\ldots \ldots \ldots \ldots \ldots \ldots \ldots \ldots \ldots \ldots 21$

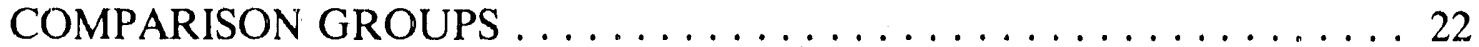

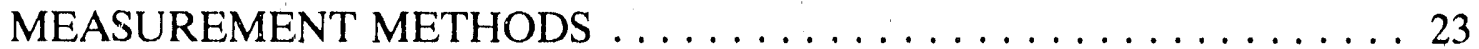

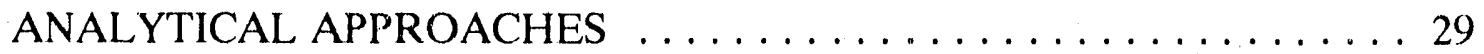

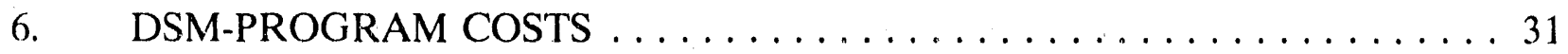

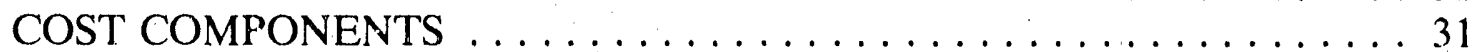

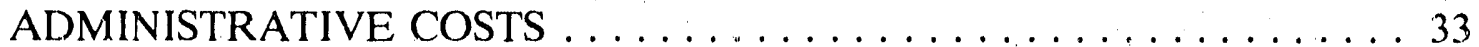

NORMALIZATION FACTORS $\ldots \ldots \ldots \ldots \ldots \ldots \ldots \ldots \ldots \ldots$

7. RECENT EFFORTS TO COLLECT DSM-PROGRAM DATA . . . . . . 37

8. FUTURE ACTIONS AND CONCLUSIONS $\ldots \ldots \ldots \ldots \ldots \ldots \ldots \ldots$

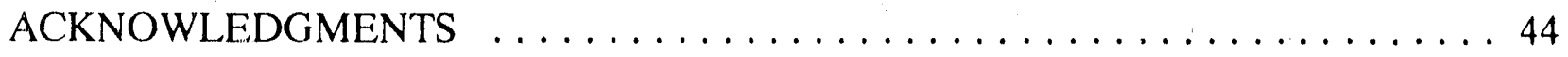

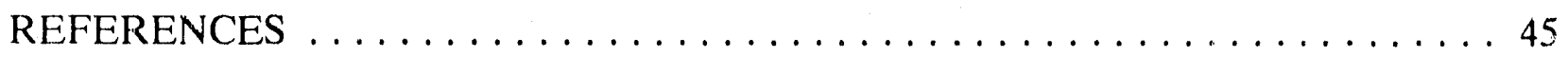

iii/iv 


\section{SUMMARY}

As the number, scope, and cost of utility demand-side management (DSM) programs increase; the need for accurate data grows. Such data are required to document the performance of these programs to be sure that they deliver the cost-effective energy and capacity resources expected of them.

Unfortunately, the amount and quality of data available on DSM programs falls far short of what is needed. Lack of explicit, widely used definitions of DSM terms is a key deficiency. Variables that describe program participation, electricity savings, and cc;sts must be carefully defined, and these definitions should then be used throughout the electric-utility industry.

For example, participation rate refers to the ratio of participants to eligible customers. Questions arise, however, over the time period used (e.g., annual vs cumulative) and definitions for both the numerator and denominator. Does the denominator include all customers eligible at the time the program began or does it correct for attrition, for past participation in the program, or both?

Reports on program energy savings need to distinguish between total and net savings. Total energy savings refer to the reductions in electricity use that program participants experience. Net savings refer to the portion of the total savings that is directly caused by the program. Such reports should also indicate the basis for these estimates. Energy savings can be computed with simple rules of thumb, engineering models, periodic measurements of electricity use, monthly' electricity bills, or end-use load monitoring. These approaches differ in their accuracy, relevance to different types of DSM programs, and cost.

Data on program costs should distinguish between utility and customer costs. It is also useful to disaggregate the utility costs for installation of equipment from administrative costs.

This report reviews DSM data-collection instrurnents developed by the Northeast Region Demand-Side Management Data Exchange, the California Public Utilities Commission, the Massachusetts Department of Public Utilities, the Maine Public Utilities Commission, the New York Department of Public Service, the New England Power Pool, and the Energy Information Administration. These formats and associated definitions can form the basis for development of standard, widely used instruments to collect, organize, analyze, and report data on utility DSM programs. 
Several steps are suggested to develop and implement improved data-collection procedures:

1. Organize a group to develop data-collection instruments on utility DSM programs.

2. Discuss and agree on the key data elements that characterize DSM programs. Priorities should be developed among these variables. Key data elements are needed at both the program-specific and the utility levels.

3. Develop consensus definitions for these terms. The output from this task could be a handbook that explains how to define, collect, manage, and analyze data on DSM programs. The definitions should recognize differences among estimates in quality and cost (e.g., engineering estimates of electricity savings vs estimates based on enduse load-research data).

4. Prepare data-collection instruments that could be used by utilities in reporting results to state regulatory commissions and to the U.S. Department of Energy.

5. Test these data-collection instruments with a few utilities and other data users to ensure that completing the forms is feasible, that the answers are valid, and that the information provided is useful.

6. Finally, implement appropriate forms at the utility, state, and federal levels. 


\section{LIST OF ACRONYMS}

DOE

DSM

ECNE

EEI

EIA

EPRI

FERC

IEEE

NEES

NEPOOL

NERC

NORDAX

PUC
U.S. Department of Energy

Demand-side management

Electric Council of New England

Edison Electric Institute

Energy Information Administration

Electric Power Research Institute

Federal Energy Regulatory Commission

Institute of Electrical and Electronics Engineers

New England Electric System

New England Power Pool

North American Electric Reliability Council

Northeast Region Demand-Side Management Data Exchange

Public utility commission 


\section{INTRODUCTION}

"Good public policy demands good information." So begins a report by the Office of Technology Assessment (1989). "There may be disagreement about the wisdom of different ... programs but there is little dispute about the need for adequate data to inform the debate."

In the energy arena, the greatest data needs concern the costs and performance of demand-side management (DSM) programs, which are likely to grow in size and importance. The interim report of the National Energy Strategy, prepared by the U.S. Department of Energy (DOE 1990) states, "The loudest single message [from the testimony prepared for DOE's public hearings] was to increase energy efficiency in every sector of energy use."

It is difficult to assess the contributions that utility DSM programs could make to resolving national energy problems because comprehensive and accurate data on such programs do not exist. As debates continue over acid rain, global warming, integrated resource planning, competitive bidding to provide resources to utilities, and energy-efficiency and load-management programs, the need will increase for comprehensive and accurate information on utility DSM programs. Such programs will increase in scope and size because of concerns about environmental quality, berause of the need to improve economic productivity, and because state regulatory commissions will provide financial incentives to utilities for implementation of successful DSM programs.

This report discusses the data that utilities collect on the supply and delivery of electricity (i.e., the production, transmission, and distribution system) and the data collected on the DSM programs they operate. It will come as no surprise to most readers that there is a substantial imbalance between the information available on these two types of resources (Hirst 1990). For example, the Energy Information Administration (EIA 1990) collects data from electric utilities on 15 different forms. EIA publishes information on the output (MW and $\mathrm{GWh}$ ) and operation and maintenance expenses of individual power plants. FIA publishes almost no comparable information on the performance and costs of utility DSM programs.

The next chapter briefly summarizes the data utilities collect on their supply systems and the management and reporting of these data by government and other organizations. Chapter 3 describes the types of data needed on utility DSM programs, and Chapters 4 through 6 discuss the elements of program participation, electricity savings, and program costs. Program performance depends on the product of the first two factors, and program cost effectiveness is a function of the ratio of performance to program costs. Chapter 7 discusses recent efforts to standardize the collection and reporting of such data. The last 
chapter suggests one way to collect, organize, manage, and use data on utility DSM programs. Implementing such data-management systems will surely improve the quality of decision making about electric-utility acquisition of resources to meet future customer energy-service needs. 


\section{DATA ON UTILITY SUPPLY SYSTEMS}

Electric utilities collect a wealth of data on the construction and operating costs of their power-supply systems, including power plants, transmission lines, distribution lines, and substations. These data guide decisions on the construction of new power plants and transmission lines, operation and maintenance of existing plants, and utility financial performance (revenues, expenses, and earnings). These data are also useful to state and federal government agencies. Public Utility Commissions (PUCs) use these data to assess utility performance and to set electricity prices. DOE uses these data to assess alternative federal policies on fuel supplies, environmental quality, and other issues.

\section{DATA FOR INDIVIDUAL POWER PLANTS}

The Electric Power Research Institute (EPRI 1986 and 1987) provides detailed information on the construction cost, construction time, and land requirements for 29 types of fossil-fuel plants, 7 types of renewable-energy plants, 2 types of nuclear plants, and 1 type of hydro plant. Estimates for at least two sizes are presented for each of these plant types. Duke Power (1990), in a recent application to construct combustion turbines, divided construction costs into 21 elements: land; power-production buildings; general-purpose buildings; fiel holders, producers, and accessories; combustion turbine/generators and accessories; accessory electrical equipment; miscellaneous power-plant equipment; transmission-plant equipment; transmission-plant towers and fixtures; general plant; earthwork; construction labor; construction plant; design engineering labor; fossil production labor; transmission engineering labor; other labor; employee expenses; initial fuel; contingencies; and allowance for funds used during construction. The existence of such detail testifies to the rich data that utilities collect on the cost of building power plants.

Similarly detailed data are collected on the operation and performance of power plants. Utilities carefully and routinely track power-plant output, heat rate, capacity factor, availability factor, and the causes and duration of all outages at each of their power plants. Utilities submit these outage data to the North American Electric Reliability Council (NERC 1988), which manages a large data base on power-plant outages and deratings (and the reasons for these outages and deratings) and on availability and capacity factors. The Council's classification system for reporting failures has almost 1500 elements. Utilities use these data, coupled with information on plant design and performance, to design new power plants and to choose maintenance and operating strategies at existing plants.

The Tennessee Valley Authority provides a good example of utility attention to power-plant performance. The utility's 950-MW Bull Run Steam Plant has a staff of 220 
people. The Technical Services Department, with 26 people, includes the coal laboratory, water laboratory, test department, and instrument department. "These technical services groups evaluate the plant's performance (Table 1).

Table 1. 1987 data for the Tennessee Valley Authority's Bull Run Sream Plant

Net peak demand on plant (MW)

Generation (GWh)

Capacity factor $(\%)$

Heat rate $(\mathrm{Btu} / \mathrm{kWh})$

Coal use

Amount burned (million tons)

Heating value (Btu/pound)

Cost $(\$ / M B t u)$

Operation expenses (mills/kWh)

Supervision and engineering

Steam

Electric

Miscellaneous

Maintenance expenses (mills/kWh)

Supervision and engineering

Structures

Boiler plant

Electric plant

Miscellaneous

Fuel (mills/kWh)

Total production expenses (mills/kWh)
900

4,756

57

8,970

11,410

1.86

2.01

0.29

0.27

0.15

0.42

0.12

0.10

1.37

0.38

0.17

18.01

21.28

The coal laboratory measures the Btu content, ash content, moisture content, and sulfur content of each trainload of coal delivered to the plant. One engineer works full time measuring the plant's heat rate and the factors that affect heat rate. He records and analyzes data on coal use, electricity output, station electricity use (for fans, conveyors, pulverizers, pumps, lighting, heating, and so on), coal quality, boiler efficiency, and steam temperatures and pressures. These data are used to compute monthly estimates of Bull Run's heat rate and to identify the reasons for deviations from the expected value. Identification of abnormal operating conditions leads to repairs by the maintenarice departments. 
The test department tests turbines, pumps, condensers, preheaters, feedwater heaters, coal pulverizers, and other equipment to be sure that these components are performing up to specifications and to detect latent problems (e.g., bearing failure) that might cause an outage. TVA maintains a detailed, computerized data base that shows all the conditions that lead to outages, based on the Generating Availability Data System developed by NERC. The system collects information on the cause of each outage and the MW-capability during the outage. These results guide the maintenance and repair activities at the plant.

TVA, like most utilities, is serious about monitoring the performance of its power plants to ensure that they operate as close to design conditions as possible.

\section{SYSTEM-LEVEL DATA}

At a more aggregate level, utilities monitor the performance of their power-supply system through such facilities as the Georgia Power Company Control Center (Allen 1990). The Center checks and regulates the flows of electricity from power plants to distribution points throughout the state of Georgia. In addition to monitoring the company's transmission network, voltage levels, and other system parameters, the center has real-time access to information from the Southern Company operations center in Birmingham, Alabama.

Figure 1 shows some of the information available on the current state of the Southern Company system. This screen shows electricity production by type of power plant, partial outages (current derate), and the amount of generating capacity available but not now used. The screen also shows production cost and the marginal cost of electricity (system lambda), the basis for short-term sales and purchases of electricity. The bottom left-hand portion shows the current values of total system load, Southern Company generation, and losses caused by in-plant use and transmission lines, all in $\mathrm{MW}$.

\section{NATIONAL DATA}

Much of the information collected by utilities for their own use is also reported to the Federal Government, in particular EIA and the Federal Energy Regulatory Commission (FERC). EIA (1989a and 1990) collects detailed information from utilities on individual power plants. These data cover construction costs and capacity; annual operation and maintenance expenses, heat rates, and fuel costs; and monthly fuel consumption, electricity generation, and availability (Table 2). EIA publishes these data in several reports. 


\begin{tabular}{|c|c|c|c|c|}
\hline SYSTEM MONITOR & $03 / 06 / 90$ & $08: 24:$ & 54 & \\
\hline GEN TYPE & $\begin{array}{l}\text { CURRENT } \\
\text { DERATE }\end{array}$ & $\begin{array}{l}\text { GROSS } \\
\text { GEN } \\
\text { (MW) }\end{array}$ & $\begin{array}{c}\text { GEN } \\
\text { RESERVE }\end{array}$ & $\begin{array}{c}\text { PROD } \\
\text { COST } \\
(\$ / h r)\end{array}$ \\
\hline FOSSIL STM & 121 & 12729 & 1871 & 238429 \\
\hline NUCLEAR & 0 & 3677 & 0 & 36935 \\
\hline COMB TURB & 22 & 60 & 1193 & 1811 \\
\hline SOCO HYDRO & 52 & 2136 & 345 & 2135 \\
\hline SEPA HYDRO & 0 & 1277 & 3 & \\
\hline TOTALS & 195 & 19878 & 3411 & 2.79310 \\
\hline $\begin{array}{l}\text { INST SYS LOAD } \\
\text { NET GEN } \\
\text { STA SER } \\
\text { SYS LOSS }\end{array}$ & $\begin{array}{c}16772 \\
19224 \\
655 \\
511\end{array}$ & SYSTEM & IAAMBDA & $\$ / M W h$ \\
\hline
\end{tabular}

Fig. 1. Sample of information available to power-system engineers on the real-time output, deratings, system load, and costs for the Southern Company.

In addition to all this, FERC Form 1 collects detailed financial information from utilities on assets, liabilities, revenues, income, cash flows, depreciation, debt, and taxes. Form 1 also covers electricity production and disposition, purchases and sales, construction costs and operating data for generating plants larger than $25 \mathrm{MW}$, costs and characteristics of transmission lines larger than $132 \mathrm{kV}$, substations, and transformers.

Other organizations, such as EPRI, Edison Electric Institute (EEI), Nuclear Regulatory Commission, and National Coal Association, also collect information and publish reports on power plants. EEI (1989b) publishes the EEI Power Statistics Data Base, which includes 12 volumes plus database diskettes with information on "design and selected operating data for more than 2,500 units in the United States and its territories [with] site and unit design data, ... customized data, and ... annual site and unit operating data." EEI's (1989a) Statistical Yearbook presents national data on generating capacity, electric power supply, generation, fuel use for electricity production, electricity sales, customers, and revenues.

The data that utilities report to ElA can be used to document power-plant performance and to explain the variations in this performance. For example, the average heat rate in 1987 for fossil-fuel plants was $12,100 \mathrm{Btu} / \mathrm{kWh}$, with a standard deviation of 6200 (EIA 1989a). Heat rates increase with plant age (Fig. 2), with increasing operating and maintenance expenses, with decreasing plant size, and with lower capacity factors. A simple 
linear regression model using these four variables explains two-thirds of the variation in heat rates across these plants.

Table 2. Some of the information required on individual power plants by the Energy Information Administration in form EIA-767

Boiler information

Monthly fuel use by fuel

Physical units

Btu content

Sulfur and ash content

Air emission standards

Particulate matter

Sulfur dioxide

Nitrogen oxides

Design pararneters

Boiler efficiency

Maximum air and steam flows

Fuel firing rate
Generator information

Nameplate rating

Monthly electrical generation

Cooling system information

Annual operations

Design parameters

Flue gas information

Flue gas particulate collector

Flue gas desulfurization unit

Annual operations

Design parameters

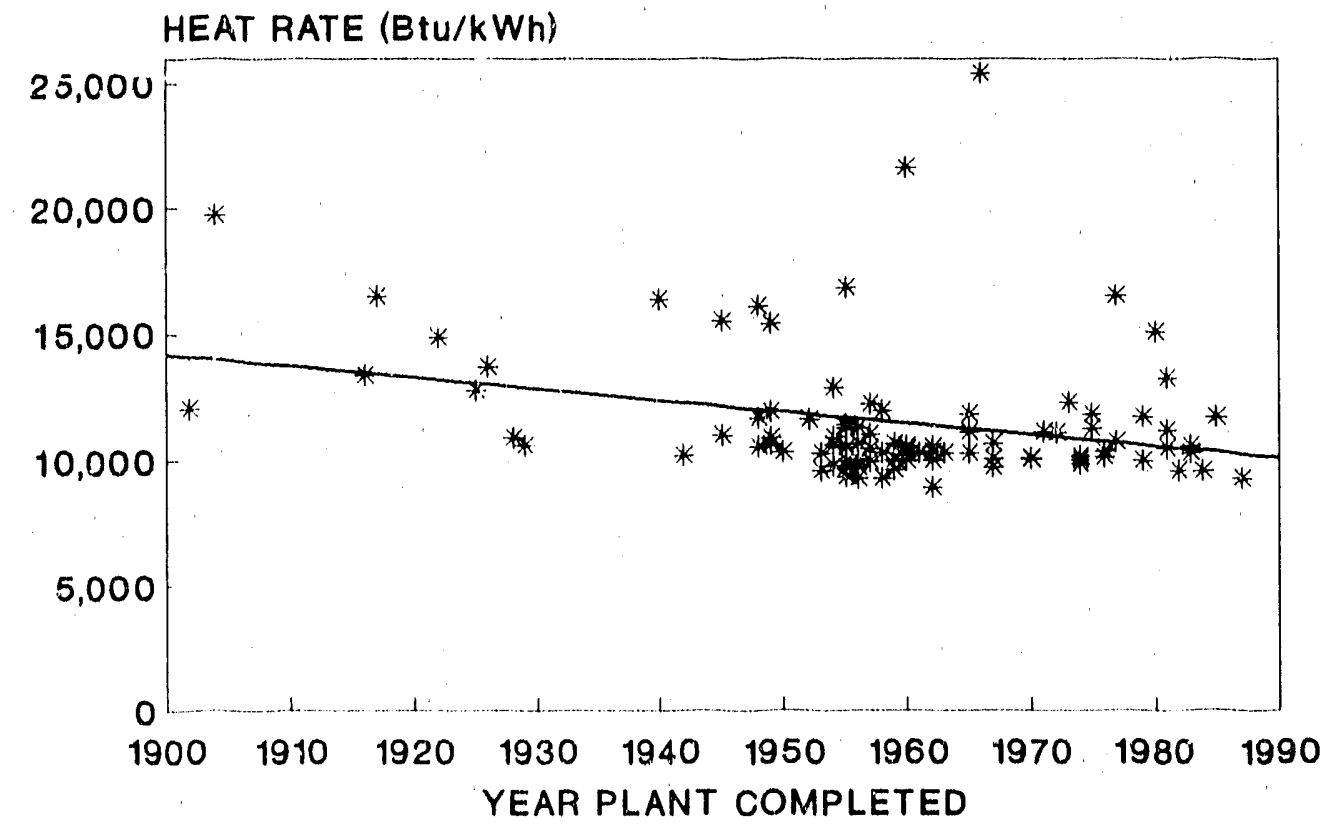

Fig. 2. Relationship between $\mathbf{1 9 8 7}$ heat rate and initial year of plant operation for 96 fossil-fuel power plants. 


\section{STANDARD DEFINITIONS}

The use of widely accepted definitions for key terms aids the collection and reporting of statistics on electric power production. For example, the Pacific Cras and Electric (1985) resource encyclopedia defines capacity factor as

The ratio of the average operating load of an electric power generating unit for a period of time to the capacity rating of the unit during that time.

And the EEI (1984) glossary defines heat rate as

A measure of generation station thermal efficiency ... computed by dividing the total Btu content of fuel burned for electric generation by the resulting net kilowatt-hour generation.

The Institute of Electrical and Flectronics Engineers (IEEE), in cooperation with the American National Standards Institute, prepares standards for various aspects of electricutility operations. For example, one IEEE standard (1987) "is intended to aid the electric power industry in reporting and evaluating electric generating unit reliability, availability, and productivity ... overcome difficulties in the interpretation of data from various systems and to facilitate comparisons among different systems ... [and] make possible the exchange of meaningful data among systems in North America ... [through the standardization of] terminology and indexes ...." Figure 3 illustrates the relationships among the terms used to define various capacity conditions for power plants.

\section{SUMMARY}

This chapter briefly documented the nearly overwhelming amount of information available on electricity production. Ultilities collect such data for individual power plants and report much of it to the federal government and others. Compilations of these data at the national level permit detailed understanding of the patterns and trends in electricity production, costs, fuel use, and other factors. For example, EEI (1989a) data on national trends in heat rate show a decline from $22,600 \mathrm{Btu} / \mathrm{kWh}$ in 1927 to 13,400 in $1952,10,500$ in 1962, and 10,300 in 1988 (Fig. 4). 
MAXIMUM CAPACITY

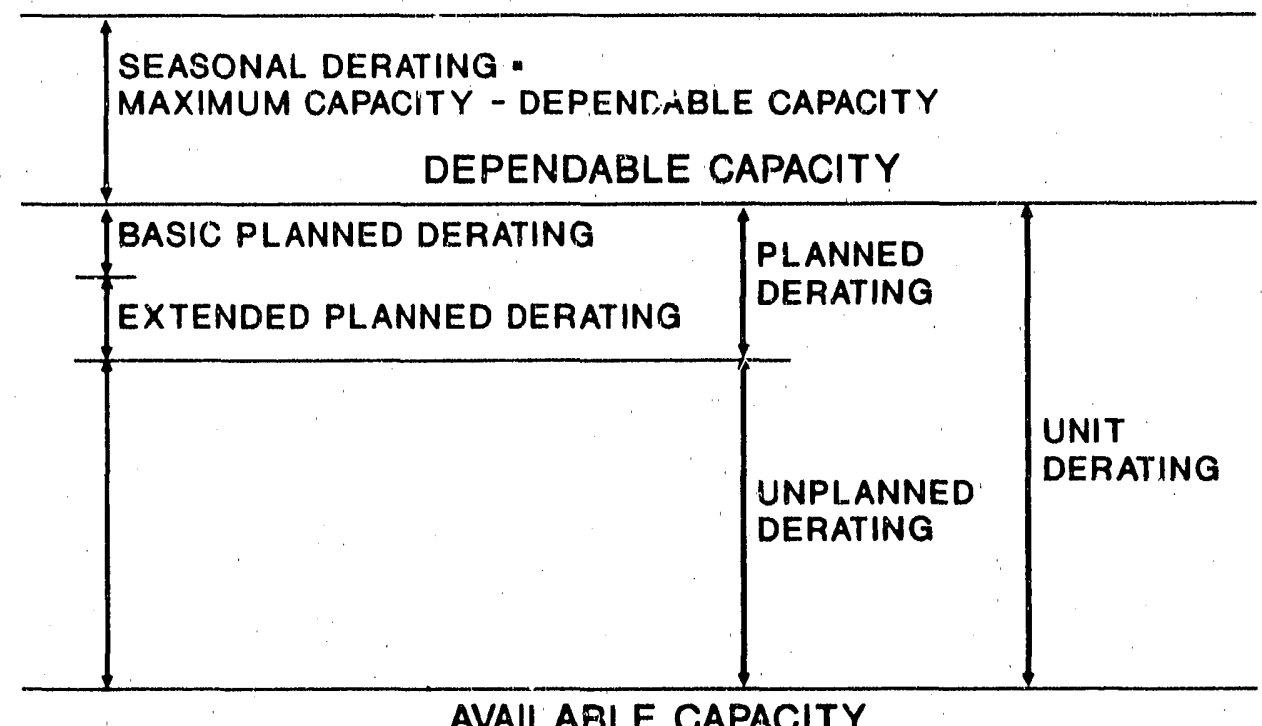

Fig. 3. A 1987 IEEE standard defines the relationships among terms that characterize power-plant capacity and deratings.

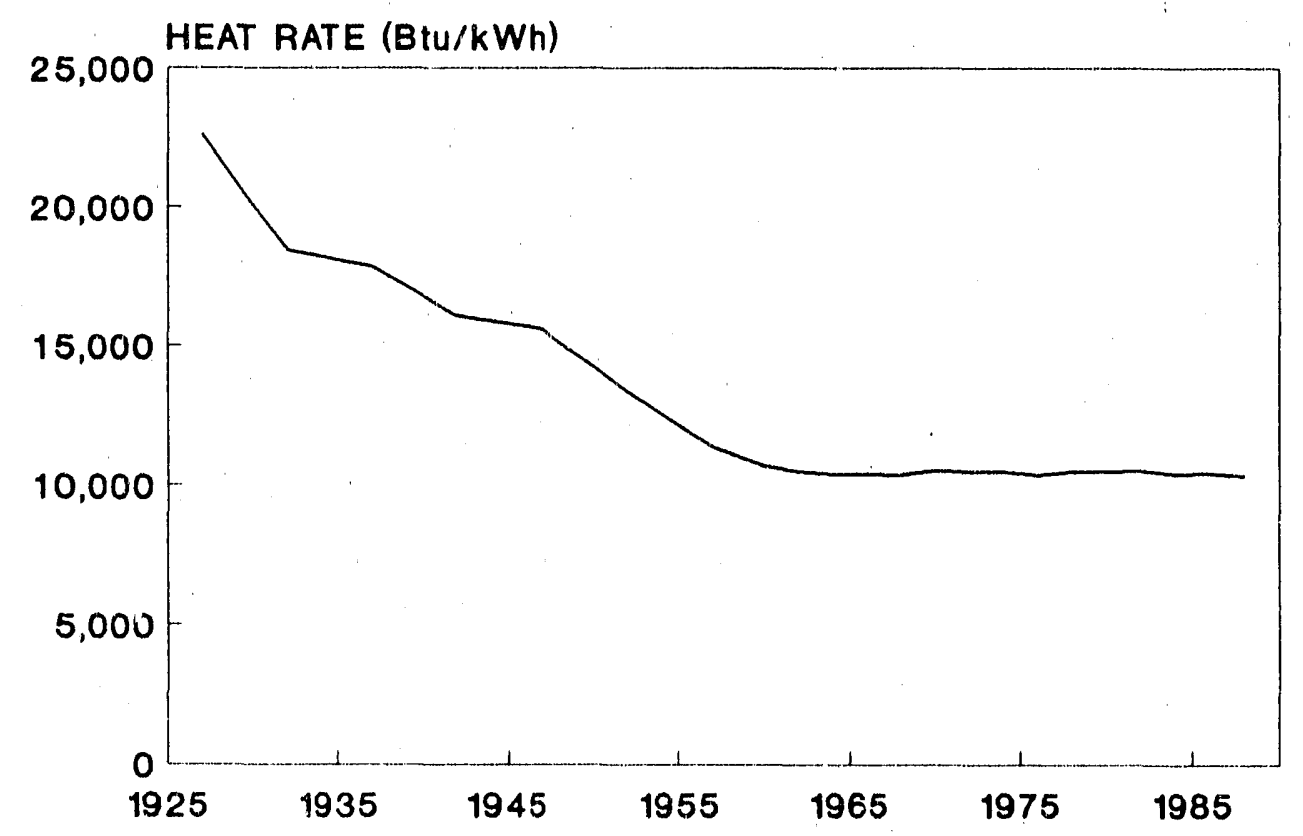

Fig. 4. National average heat rate for electric power plants, 1927 through 1988. 


\section{KEY CHARACTERISTICS OF UTILITY DSM PROGRAMS}

The overall value of a utility DSM program is a function of four factors: (1) program participation, (2) participant adoption of recommended actions, (3) electricity savings caused by these actions, and (4) utility and customer costs of the program (Hirst 1987). Roughly speaking, the value ${ }^{\#}$ of a program depends on the product of the first three factors divided by the fourth factor (ulectricity effects/costs). Assessing the benefits and costs of DSM programs requires accurate data, based on clear and widely used definitions, for each of these factors. The following three chapters discuss definitions of program participation (Chapter 4 ), program energy savings (Chapter 5), and program costs (Chapter 6). For simplicity, adoption of recommended actions is implicitly included in the discussion of electricity savings.

The cost and performance of utility DSM programs are complicated by other factors, including:

- existing stocks of buildings and electricity-using equipment;

- the availability, cost, and electricity-use characteristics of end-use technologies;

- the attitudes and behaviors of customers who install and use these technologies;

- the attributes of utility DSM programs, including marketing, staff, content and format of the information provided, incentives, quality control, and so on; and

- the external environment, including electricity prices and economic growth.

These factors interact with each other and change over time. Therefore, utilities should collect information, not just on the four factors listed above, but also on the determinants of these direct factors. This additional information can be used to design and run better DSM programs. For example, information on how different groups of customers responded

"Utility DSM programs include efforts to increase overall sales (especially during offpeak periods) and alternative rate structures to affect the timing of electricity demand, as well as programs aimed at improving energy efficiency and reducing peak demands. Only the latter program types are considered here.

\#Program benefits often include more than reductions in electricity use and demand. Such benefits, not discussed here, include customer satisfaction, reduced use of wood for residential space heating, and increased output from industrial facilities. 
to different types of advertising can be used to improve the cost-effectiveness of program marketing. 


\section{DSM-PROGRAM PARTICIPATION*}

Participation in utility DSM programs depends on various factors, including the utility's supply of services (program budgets, personnel, and materials) and the demand for these services. Supply constraints often limit participation as much as, or more than, other factors do. With strong utility commitment to gaining high penetration, participation depends on the match between the services offered and the rieeds of the relevant customer segments. Thus, participation depends on the ability of the utility to identify and remove the most important barriers (e.g., lack of information, time, confidence in DSM technologies, or capital) facing different groups of eligible customers.

Utilities define program participation rates as the ratio of the number of participants to the number of customers eligible for the program for a specified unit of time. Unfortunately, no standard definitions are widely used in calculating and reporting program participation. Ambiguities arise over annual vs cumulative figures; the definition of "participants;" the definition of "eligible nonparticipants;" and the differences among retrofit, replacement, and new markets.

It would aiso be useful if utilities collected information on the factors that affect participation (e.g., marketing approach used, type and amount of financial incentive, DSM technologies promoted, customer groups targeted for participation, community characteristics, and years the program has been in existence) (Fig. 5). Such data, analogous to that compiled by NERC in its Generating Availability Data System for power plant outages, would help utilities in designing programs that achieve high participation rates.

\section{PARTICIPATING UNITS}

The best definition of a participating unit varies from program to program. In some cases, the number of customers (e.g., the number of homeowners or businesses participating) may be the most appropriate measurement unit. In other cases, the number of equipment purchases or items installed through the program (such as the number of high-efficiency refrigerators, motors, or lamps) may be the most appropriate measurement unit. For the commercial sector, within which buildings differ greatly in size and energy intensiveness, floor area may be the preferable measure of participation.

A participating unit may refer to a person, a building, a business, a meter, or an account. Because these varying definitions can produce quite different numbers, the denominator must be defined in the same way as the numerator of the participation rate.

"Much of the material in this chapter is from Berry (1990). 


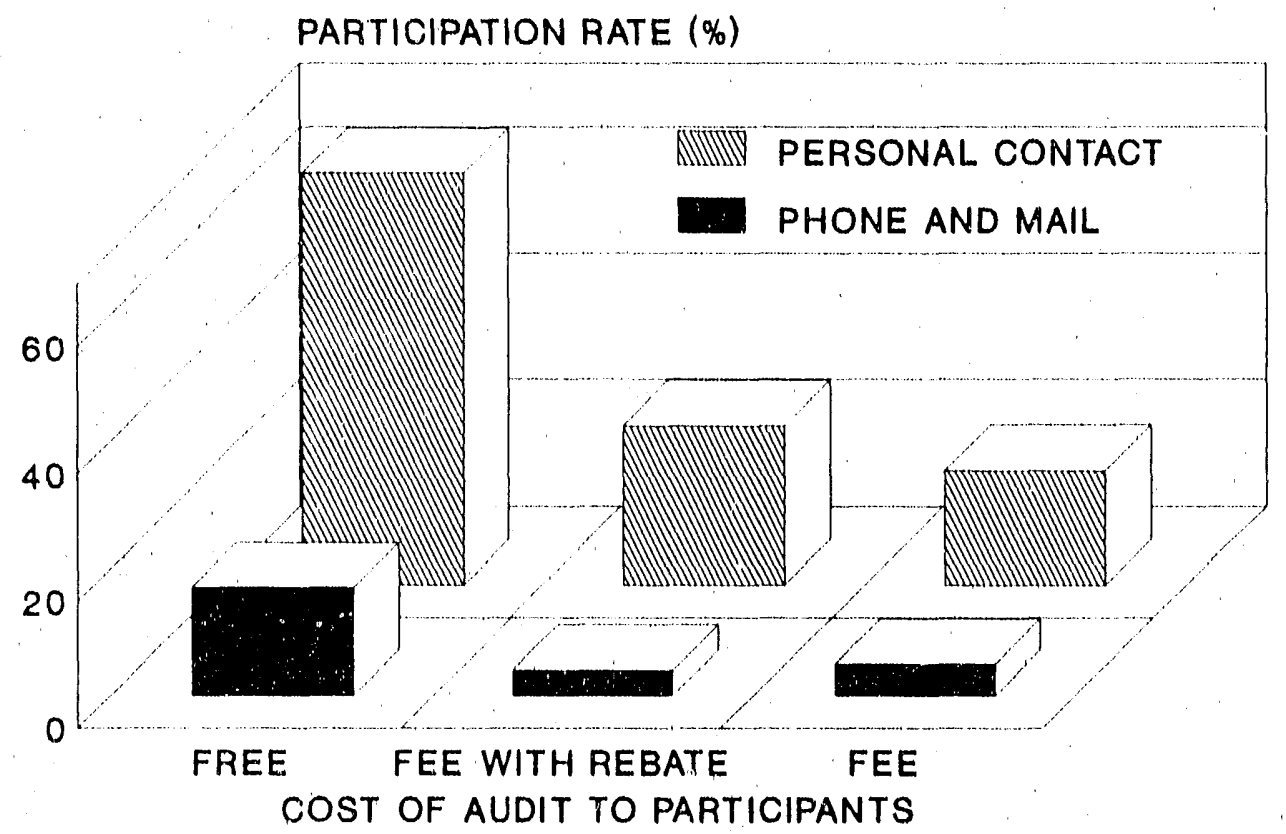

Fig. 5. Percentages of commercial customers accepting an energy audit offered by New York State Electric and Gas Corporation, by marketing approach and cost to the customer (Xenergy 1989).

Program participation is often defined as a customer's acceptance of any of the services or technologies provided by a DSM program. This definition, which uses the number of customers to track participation, is most useful for building audit and retrofit programs, for new construction programs, and for load control or rate programs. When the customer is used as the unit of measurement and several technologies are offered by a program, utilities often define a typical package of technologies and base estimates of electricity savings on this package (not on the separate impacts of individual energy-efficiency actions).

For some equipment programs (such as motor, ballast, or lamp rebates), participation rates are best defined as the number of pieces of equipment installed through a program divided by the total number installed during the year. In such cases, penetration is not measured in numbers of customers because a customer may acquire multiple units of a particular type of equipment. In addition, only a portion of the equipment is replaced each year, and only a portion of annual purchases meets a program's rebate eligibility requirements. Therefore, the number of high-efficiency items installed through a program can be compared to the number of low-efficiency items still in use to determine the cumulative penetration for all the equipment that could be replaced. 
Audit programs combined with financial incentives pose another definitional problem. In this case, the number of participants can include both audit-only and audit-plus-incentive users or include only the users of the financial incentive. The choice between these definitions affects results. Audit-only customers may not be eligible for program incentives because of physical barriers or because their buildings do not meet cost-effectiveness tests. They also may choose not to accept the incentive offers for which they qualify. The situation may be even more complicated for programs aimed at large commercial buildings and industrial factories. Such programs might involve several site visits to the facility over the course of a few years.

\section{ELIGIBLE CUSTOMERS}

Defining the number of eligible customers (the denominator for a participation rate) is rnore difficult than defining the number of participants. Market surveys, appliance saturation surveys, building inspections, and sales data are often used to estimate the number of customers who could adopt specific DSM actions. Eligibility may depend on fuel choice (e.g., customers might be required to have an electric water heater to participate in a particular program).

For some technologies, it is difficult or impossible to determine the number of eligibles. It may not be possible, for example, to determine the number of buildings that could install high-efficiency motors without inspecting many buildings. Eligibility changes over time as some of the eligible units install the technology and some buildings and equipment are retired.

For convenience and because of a lack of data, the eligible population is often defined as all of the utility's customers in a certain class. In most cases, the number of customers who could actually adopt the actions will be smaller than the total customer base. Therefore, using the total number of customers as a denominator may artificially reduce estimates of participation rates. This effect may be especially significant in the commercial and industrial sectors because customers who have more than one meter at a facility may be counted several times or because minimal-use facilities may be incorrectly counted (e.g., a phone booth or a billboard may have a meter and an account). Minimal-use facilities can account for about $40 \%$ of commercial and industrial customers, and multiple meters at the same facility may account for as many as $10 \%$ of such accounts (Nadel 1990).

In audit programs, the participation rate is quite sensitive to whether eligibility is defined as all customers who could receive audits or as only those found eligible after an audit is performed. Krause, Vine, and Gandhi (1989) give two examples of how definitions of eligibility for commercial lighting programs affected participation rates. In a Sacramento Municipal Utility District program, the cumulative participation rate based on the total number of customers in the targeted rate class was $25 \%$. When participation was calculated on the basis of eligibility as determined through onsite audits, the rate was $58 \%$. A New 
England Electric System program showed similar effects: $34 \%$ participation based on the whole target group and $55 \%$ based on audit-determined eligibility.

While counting all accounts as eligible often reduces rates below their correct value, a rate also may be artificially high because the number of customers defined as eligible is very small. A few commercial programs designed to target only the service area's largest customers, for example, have participation rates close to $100 \%$. In these cases, the number of customers defined as eligible only included a few buildings. Therefore, the results cannot be generalized to larger markets.

Pilot programs can produce artificially high or low rates. Pilot programs may not aim to achieve high penetration and may purposely limit the supply of services, producing low participation rates. Alternatively, a pilot effort may target only a small number of eligible units, producing a high participation rate.

\section{TIME PERIODS}

The number of participants and the number of eligible customers used to calculate a participation rate should represent the same period. A clear distinction should be made between annual and cumulative rates. An annual rate covers one-year increments from the program's starting date. A cumulative rate covers all the time elapsed since the starting date. Because reports of cumulative rates may include different lengths of time, it is difficult to compare them. Cumulative rates would be more comparable if they were divided by the number of years the program operated to yield an average annual participation rate. Cumulative rates are useful for seeing how much of a market is tapped and how much is still available. Since both annual and cumulative rates have important uses, both should be reported.

\section{RETROFIT VERSUS REPLACEMEN'T MARKETS}

The eligible market for a DSM program can include retrofits, equipment replacements, new construction, or some combination of the three. (Remodeling an existing building is more like new construction than retrofit; programs aimed at remodeling might best he treated as new-construction programs.) The dynamics of market penetration differ for retrofits versus replacements and new construction. While it is feasible to achieve high levels of cumulative penetration (i.e., $80 \%$ or more) in several years for retrofits, a replacement or new-construction market saturates over a longer time frame. A complete turnover of the existing stock is necessary for a replacement market to reach saturation. The refore, a decade or more may pass before all of the potentially eligible equipment wears out and opportunities for replacement occur. 


\section{$\underline{\text { Retrofit Programs }}$}

For retrofit programs, the number of eligible customers may be defined as all those who could physically accept the load-control device or the energy-efficiency measures. Alternatively, eligibility may be limited to customers who meet certain cost-effectiveness criteria; who use elecric space heat, or who consume a large amount of electricity. Eligibility also may be limited to certain building types or to buildings constructed before a certain date. An attic insulation program, for example, may target all homes built before 1985, that use electricity for heating, and that have less than R-19 in their attics. The pool of eligible customers will usually decrease with time as DSM actions are taken and units are retired.

In direct load control and rate programs, much of the same pool of customers remains eligible over the lifetime of the program. Therefore, annual participation rates tend to be high because customers who began participating in one year are typically counted as participants in each subsequent year. Thus, annual rates for load control and rate programs have magnitudes similar to cumulative rates. In retrofit programs, in contrast, annual rates are typically much smaller than cumulative rates because participants "graduate" from the program when their retrofits are completed.

Annual rates are defined as the number of participants divided by the number of those eligible in a given year (Table 3). Cumulative rates may be defined in terms of the base year stock or the stock that is still eligible in the current year. The first definition shows what percentage of the units that were initially eligible have participated in the program. The second definition shows how much of the potential for efficiency improvements in the current stock has been captured. With the same number of participants, cumulative rates can vary depending upon the rate of attrition (the fraction of existing buildings that are retired from the stock each year) and the definition of the eligible population that is used (Fig. 6).

\section{Replacement Programs}

For replacement or new-construction markets, the membership in the pool of eligible customers changes each year. For appliances, the fraction of the stock that fails and has to be replaced will constitute most of the market in a given year. In addition, new purchases or early-replacement purchases (a number so small that it is often ignored) will contribute to the eligible pool. High-efficiency refrigerators, water heaters, and air conditioners are good examples of this type of market. The initial stock of equipment and the rate at which the stock is replaced determine the size of the eligible market (i.e., the number of customers making purchase decisions in a given period). In this case, the number of eligibles used for determining annual rates should be defined as the number of customers eligible for the program who replaced the equipment during that year.

Cumulative rates can be defined in terms of the total number of appliance purchases to date or the stock of eligible appliances in the current year (Table 3). The first definition. 
shows the cumulative percentage of appliance buyers (or the percentage of new huil angs constructed) that participated in the program. The second definition shows the percentage of high-efficiency units in the current stock. For replacement markets, annual rates are often higher than cumulative rates because the denominator, annual purchases, is smaller (Fig. 7). Cumulative rates vary depending upon the attrition rate and the definition of the eligible population.

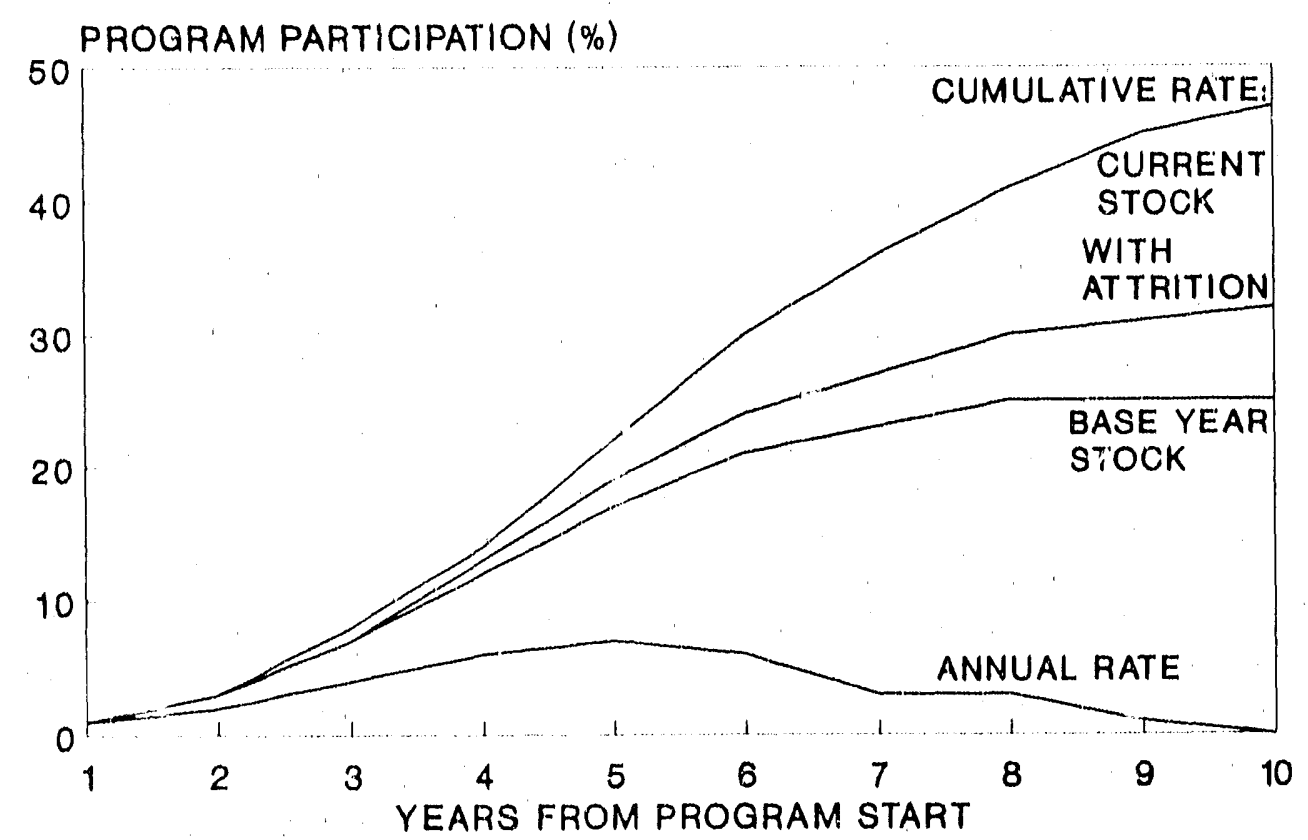

Fig. 6. Comparison of annual and cumulative market penetration rates for a retrofit market (Berry 1990). The annual rate is the ratio of the number of participants to the number of customers eligible that year (which accounts for attrition and prior participants). Three different measures of cumulative participation are shown.

Because of differences in the dynamics of retrofit versus replacement markets, their patterns of annual and cumulative rates differ (Figs. 6 and 7). For retrofit markets, annual rates first increase, typically peaking in the middle phase of a program's lifetime, and then decline as fewer units are eligible for the retrofit measures. Cumulative rates follow an S-shaped curve until a saturation level is reached (Fig. 6). For replacement and newconstruction markets, annual rates increase as knowledge about the program spreads among those eligible to participate. Cumulative rates also increase, but take longer to reach maximum levels (Fig. 7). 
Table 3. Alternative definitions of program participation rates

RETROFIT

Arnual $\quad$ Number of units participating in year $i$

Number of eligible units in year $i$

Cumulative Number of units participating since program inception

Number of eligible units from program inception year that are still eligible (base year minus attrition minus past participants)

or Number of units participating since program inception

Number of eligible units in the base year

REPLACEMENT (Appliances, equipment, or new construction)

Annual Number of units participating in year $i$

Number of appliances purchased (or new units constructed) in year $i$

Cumulative Number of units participating since program inception

Number of appliances purchased (or new units constructed) from year program started through year $i$

or Number of units participating since program inception

Number of eligible units currently in service (base year minus attrition minus past participants plus eligible units added to stock since base year)

\section{NEED FOR S'TANDARD DEFINITIONS}

Unfortunately, no standard definitions are used consistently in reporting participation rates. Definitions of the eligible population and explanations of how membership in this population changes with time are typically not presented. The period covered is often unspecified. As a result, it is difficult to know how comparable information from various sources on participation rates may be. The use of standard definitions and explanations of the composition of the eligible population are needed to improve the usefulness of data on participation rates.

The Northeast Region Demand-Side Management Data Exchange (NORDAX 1989) data base makes an important contribution to the development of clear and consistent definitions. NORDAX is a consortium of about 30 utilities and related organizations, established in 1987 to collect, organize, and make available to its members data on electricutility DSM programs. NORDAX provides an initial model of a comprehensive set of 
categories to use in defining, collecting, and organizing data on DSM programs in a standard format. NORDAX definitions of annual penetration rates are the same as the ones presented in Table 3 for retrofit and replacement markets. NORDAX definitions of cumulative rates are the same as the first definitions given in Table 3 for cumulative rates in both the retrofit and replacement markets.

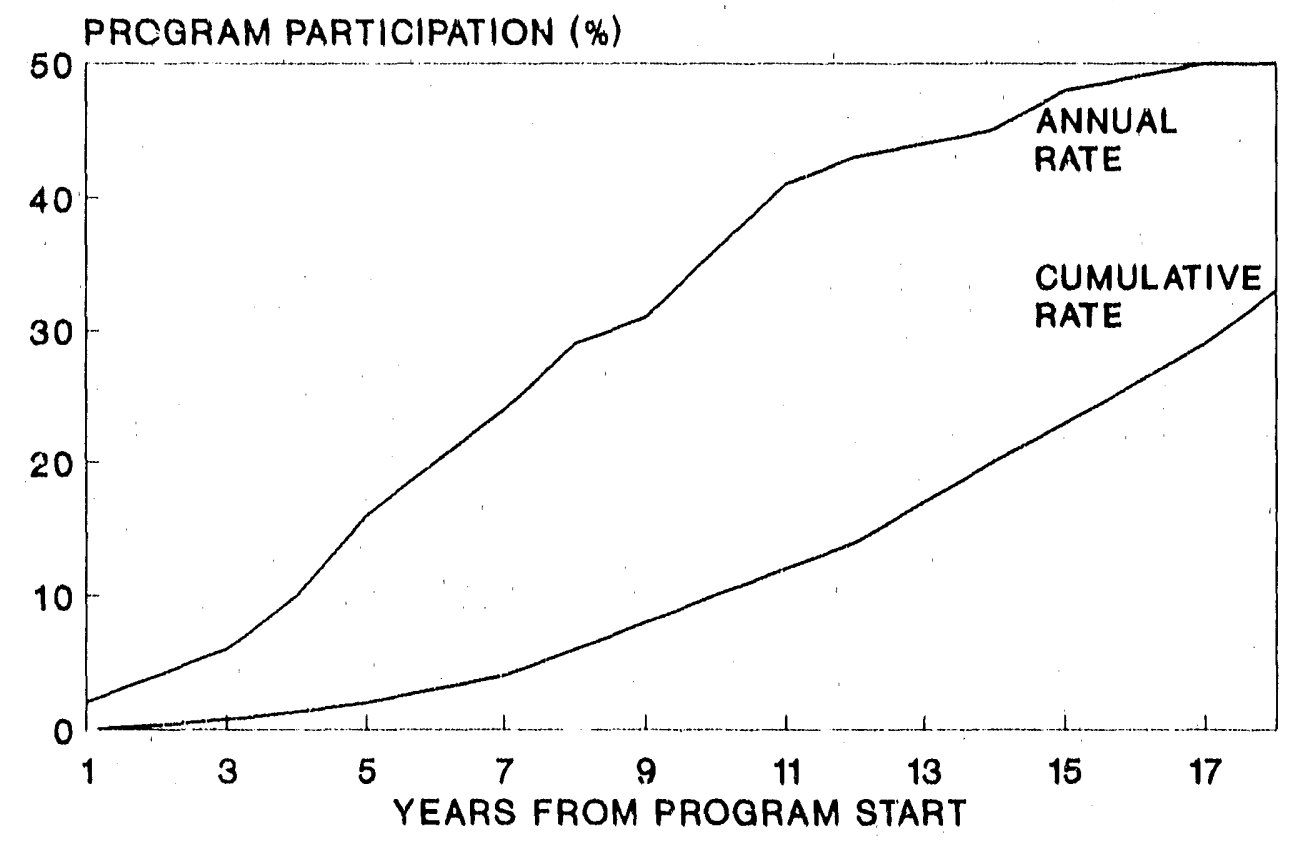

Fig. 7. Comparison of annual and cumulative market penetration rates for a replacement market (Berry 1990). The annual rate is the ratio of the number of participants to the total number of purchases that year. The cumulative rate is the ratio of the number of participants since the program began to the number of eligible units that year. 


\section{DSM-PROGRAM ELECTRICITY SAVINGS}

The literature on program evaluation contains many examples of different ways to define and measure the changes in electricity use, load shape, and peak demand stimulated by DSM programs (Keating 1988; Argonne National Laboratory 1989). Key issues to consider include the distinction between first-year and long-term electricity savings, differences between demand reductions at the time of winter and summer system peaks (and demand reductions at the time of system, class. or customer peaks), and the effects of changes in equipment performance and customer behavior after participation in a program.

\section{NET VERSUS TOTAL SAVINGS}

In examining electri ity savings, utilities must decide whether they want to measure (1) electricity savings caused by utility-sponsored installations of DSM systems or (2) electricity savings realized in the facilities of participating customers that would not otherwise have occurred. Protocols were developed to measure the costs and energy savings of new end-use technologies; see, for example, MacDonald, Sharp, and Gettings (1989) for a discussion of protocols for commercial buildings.

Such an approach, which focuses on the savings caused by the DSM actions, identifies the total savings, the reduction in electricity use experienced by customers that participate in the program. Net savings is the portion of the total savings that can be directly attributed to the program. Thus, net savings are the difference between total savings and the savings that participants would have achieved on their own had the utility program not existed." A comparison group is often used to estimate what participants would have done in the absence of the program. Figure 8 shows the net and total electricity savings caused by the pilot Residential Weatherization Program run by the Bonneville Power Administration (Hirst et al. 1985).

The distinction between total and net savings may be more theoretical than practical for some DSM prograns. If utilities focus on large commercial and industrial customers (most of whom are exposed to the program) and emphasize advanced technologies that are not yet widely available, then the difference between net and total savings is likely to be quite small.

"The ratio of net to total savings can be greater than 1.0. Consider, for example, a situation in which electricity prices are declining and incomes are rising; without the program, electricity use might increase so that net savings would be greater than total savings. 


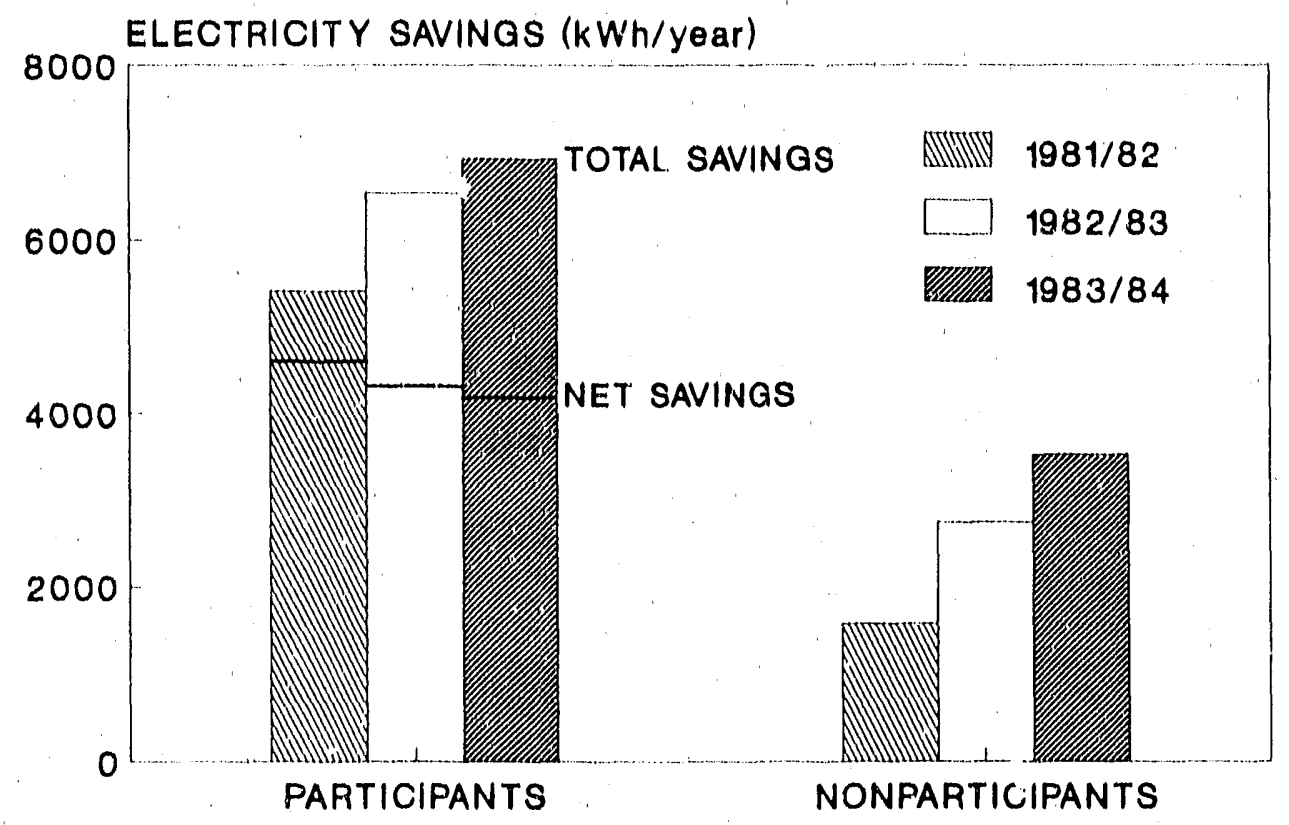

Fig. 8. Total and net electricity savings for participants in the BPA pilot Residential Weatherization Program. The reductions in electricity use achieved by nonparticipants was probably stinulated primarily by rapidly rising electricity prices during the early $1980 \mathrm{~s}$.

\section{COMPARISON GROUPS}

Some type of comparison is needed to identify net energy savings. A group of nonparticipating customers is often used as a comparison group. The more closely this group resembles the participants, the more accurate will be the estimates of net savings. In some cases, especially for programs aimed at large commercial and industrial customers, a suitable comparison group cannot be found because all such customers are either participants or have received offers to participate in the program. In such cases, time-series (historical) data on the participants might cerve as a suitable comparison. Analysis and extrapolation of preretrofit trends in electricity use can approximate the electricity use in these facilities without the utility program. Alternatively, later participants in a DSM program can serve as the comparison for earlier participants.

Comparison groups are needed for load-management programs as well as for energyefficiency programs. Participants can often be used as their own comparison group for direct load-control programs. Load-shape data for noncontrol days with similar weather (e.g., ambient temperatures) are sometimes used as a reference against which to assess the load reductions on control days. Alternatively, statistical analysis of load shapes on several control and noncontrol days can be used to infer the load reductions caused by the utility program (Caves, Lowry, and Wharton 1989). 
Free riders are customers that participate in a utility program, but would have adopted the recommended actions even without the program. Utilities will want to design programs to minimize (and measure) this effect. In particular, when electricity prices are rising rapidly or new energy-efficient technologies are entering the market, the difference between net and total savings can be large. Under such conditions, utilities will end up paying for some DSM actions that would have been installed even without the program.

Comparison groups are also needed to identify "takeback," the extent to which customers that participate in a DSM program modify their energy-use behaviors after participation. For example, households might increase indoor temperature settings after participating in a retrofit program, because the cost to heat their homes is now lower than it was before retrofit. An industrial customer might increase production after installation of efficient motors because the lower production costs make the factory more competitive. While such takeback reduces the amount of energy resource available to the utility, takeback may not be a cost to the program. On the contrary, the increase in comfort or economic output may be an important benefit to participating customers and may help the utility improve customer service. Measuring the existence and size of takeback generally involves analysis of electricity-use data for both the participants and a comparison group of nonparticipants.

\section{MEASUREMENT METHOIS}

Measurements of electricity use and savings can be based on simple engineering factors, engineering calculations, special short-term metering (e.g., a few weeks of kWdemand ineasurements before and after retrofit), customer monthly electricity bills, wholebuilding load-research data, or end-use load monitoring (i.e., time-of-use measurements of electricity use by end use); see Table 4. Some of these approaches (i.e., the engineering methods) focus on the energy savings caused by installation of DSM equipment, while other approaches (e.g., analysis of electricity-use data) focus more on the effects of DSM programs.

Not surprisingly, the more accurate the system used to measure energy savings, the more costly it "'ill be. Also, the type of measurement required depends on the type of program and on the DSM actions taken.

For a DSM program that includes a variety of actions, the installation of which depends on the individual circumstances at each customer facility (e.g., retrofit of the building envelope), site-specific measurement provides the best way to estimate saved electricity. At the other end of the spectrum (e.g., installation of equipment with which utilities have substantial experience, for which savings are largely invariant across customers and utilities, and for which savings have been measured in the past), measuring the savings yet again is not necessary. In such cases, past measurements and/or engineering calculations can be relied on. 
Table 4. Methods used to measure electricity savings

\begin{tabular}{|c|c|c|c|}
\hline Approach & Explanation $^{a}$ & Advantages & Disadvantages \\
\hline $\begin{array}{l}\text { DSM-action- } \\
\text { specific } \\
\text { factors }\end{array}$ & $\begin{array}{l}\text { Standard factors for } \\
\text { certain actions are } \\
\text { determined beforehand, } \\
\text { which form the basis for } \\
\text { estimation. }\end{array}$ & $\begin{array}{l}\text { Very simple, no } \\
\text { ambiguity, very low } \\
\text { administrative cost. }\end{array}$ & $\begin{array}{l}\text { Valid for only some } \\
\text { devices, could yield } \\
\text { estimates of savings not } \\
\text { realized if factors are } \\
\text { incorrect or inappropriate } \\
\text { or if devices fail to } \\
\text { perform as expected. }\end{array}$ \\
\hline $\begin{array}{l}\text { Engineering } \\
\text { calculations }\end{array}$ & $\begin{array}{l}\text { Calculations of expected } \\
\text { electricity savings are } \\
\text { performed for each device } \\
\text { in each building, may } \\
\text { involve simple formulas } \\
\text { or computer models. }\end{array}$ & $\begin{array}{l}\text { Simple, no ambiguity, low } \\
\text { administrative cost. }\end{array}$ & $\begin{array}{l}\text { Could yield estimates of } \\
\text { savings not realized if } \\
\text { calculations are incorrect } \\
\text { or inappropriate or if } \\
\text { equipment fails to } \\
\text { perform as expected. }\end{array}$ \\
\hline $\begin{array}{l}\text { Periodic } \\
\text { measurements } \\
\text { of electricity use }\end{array}$ & $\begin{array}{l}\text { Monitor electricity use } \\
\text { before and after } \\
\text { participation for short } \\
\text { times (e.g., a few days), } \\
\text { also measure other } \\
\text { relevant factors (e.g., } \\
\text { operating hours for } \\
\text { equipment, heating } \\
\text { degree days) for a longer }\end{array}$ & $\begin{array}{l}\text { Measures electricity } \\
\text { savings (both kWh and } \\
\mathrm{kW} \text { ) for well-defined, } \\
\text { short time periods. } \\
\text { Modest cost. }\end{array}$ & $\begin{array}{l}\text { Could yield estimates of } \\
\text { savings not realized if } \\
\text { measurements taken } \\
\text { incorrectly or at atypical } \\
\text { times, or if building use } \\
\text { changes. Difficult to } \\
\text { apply to devices that are } \\
\text { season- or weather- } \\
\text { dependent. }\end{array}$ \\
\hline
\end{tabular}

Analysis of monthly electricity bills

End-use, loadresearch monitoring

$$
\text { time (e.g., up to a year). }
$$

Obtain electricity bills for a year before and a year after participation, adjust annual electricity use for weather and other relevant factors, compute difference between preand post-participation use in $\mathrm{kWh} /$ year.

Monitor specific circuits affected by new systems to record $\mathrm{kW}$-demand both before and after participation.
Measures actual changes in electricity use, permits adjustment for changes in weather and other factors, requires little primary data collection.

Measures actual changes in electricity use and demand ( $\mathrm{kWh}$ and $\mathrm{kW}$ ) for specific end uses affected by program. Combine $\mathrm{kW}$ information with other data to adjust for changes ir weather and other factors.
Provides no estimate of demand $(\mathrm{kW})$ reductions. Analysis of monthly billing data can yicld ambiguous results. Estimates of $\mathrm{kWh}$ savings affected by changes in facility use unrelated to devices installed.

Most expensive and time consuming method. Large amounts of data require sophisticated computer programs and analysts to interpret. Results may be affected by changes in facility use unrelated to equipment installed.

The latter three approaches can use pre- vs post-participation data for program participants, data for participants vs a comparison group, or both methods. 
The simplest system for estimating electricity savings is engineering estimates (the first two entries in Table 4). Unfortunately, evidence (e.g., Hirst et al. 1985) indicates that engineering calculations typically yield estimates of electricity savings higher than actually achieved. Also, estimated and actual savings vary substantially in individual facilities (Figs. 9 and 10). However, for some DSM actions (e.g., insulation wrapped around a residential water heater), this approach can yield reliable estimates of energy savings.

The New England Electric System (NEES) (Michaels 1988), in the design of its DSM bidding program, examined the use of standardized engineering estimates to determine electricity savings. NEES concluded, from an analysis of energy audits on 300 commercial buildings, that it could define standard factors for certain technologies that were frequently recommended, were generally cost effective, and had a consistent and predictable impact on the building's load shape. From these energy audits and estimates of time-differentiated marginal costs, "demand reduction adjustment factors" were developed for these technologies (Table 5):

\section{$\$$-value of the savings for ten years per peak-kW reduction}

$\$$-value of a $1-\mathrm{kW}$ reduction for every hour for ten years

These factors accounted for the number of hours a year that the technology would contribute to load reduction, the value to NEES of that load reduction, and the number of years the technology was expected to last. An action with a 10-year lifetime that cuts demand by $1 \mathrm{~kW}$ for all 8760 hours per year would have an adjustment factor of 1.0 . An action with only a 2-year lifetime that cuts demand by $1 \mathrm{~kW}$ during only a few offpeak hours might have an adjustment factor of less than 0.01 .

This approach involves verification only of the options installed and no measurements of electricity use or savings. This is the simplest and least expensive method for estimating electricity savings. Unfortunately, it is often the least accurate.

A more expensive, complicated, and accurate method to determine savings involves special, periodic measurements of electricity demand. This approach, used by Boston Edison (1989), measures electricity demand (typically recorded at 30-minute intervals for 30 days) on circuits affected by the particular DSM actions taken (Table 6). Boston Edison used this method to estimate savings for lighting, motors, and HVAC controls. Such measurements are taken at least twice, once before retrofit and once after retrofit. Monthly or annual electricity savings are then computed on the basis of the difference in pre- and post-retrofit electricity use, adjusted for the number of hours per month (or per year) that the system is in operation. This method is suited for large commercial buildings and industrial facilities, which often have regular operating schedules and use electricity for many different purposes. 


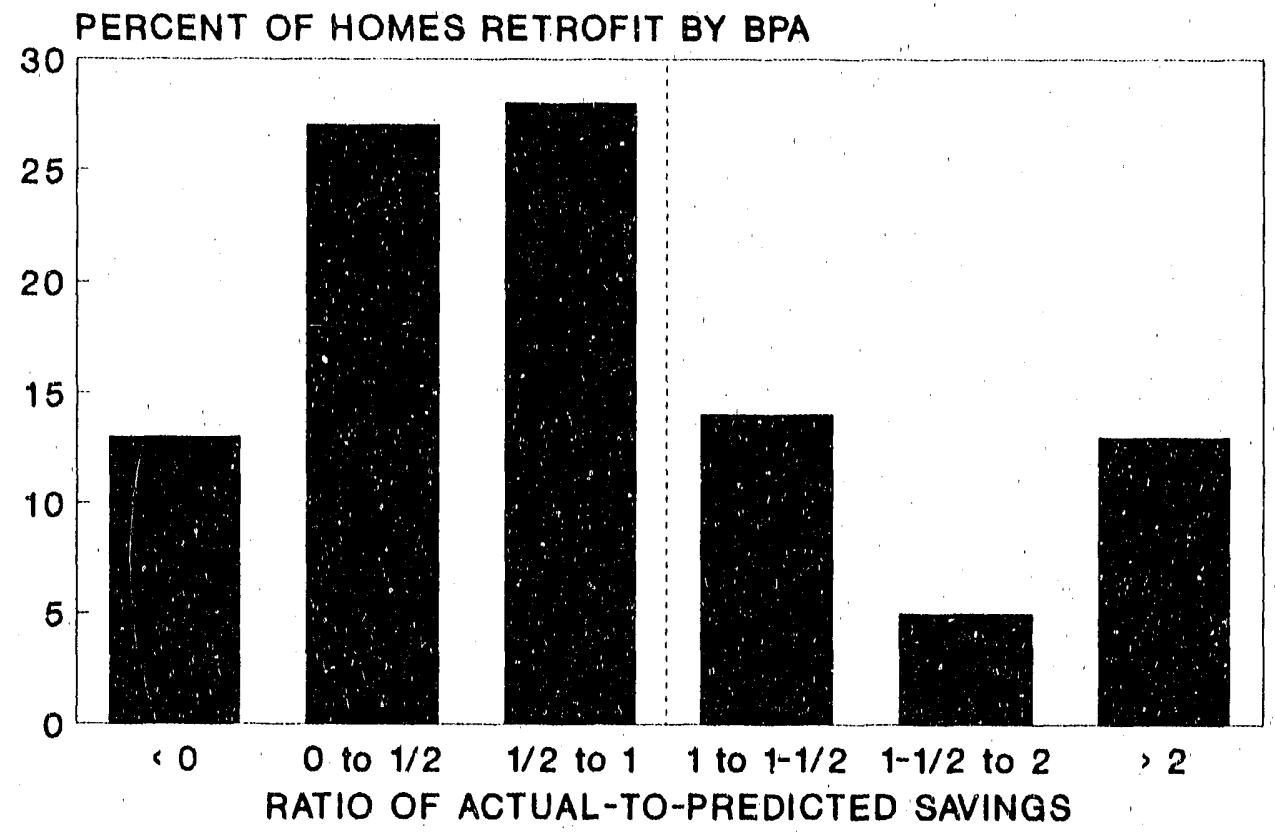

Fig. 9. The ratio of actual-to-predicted electricity savings for homes retrofit in 1981 by the Bonneville Power Administration's pilot Residential Weatherization Program. Actual and predicted savings are equal on the dashed line. Homes to the right of this line saved more than expected and homes to the left saved less than expected.

ACTUAL SAVINGS $\left(\mathrm{kWh} / \mathrm{ft}^{2}\right)$

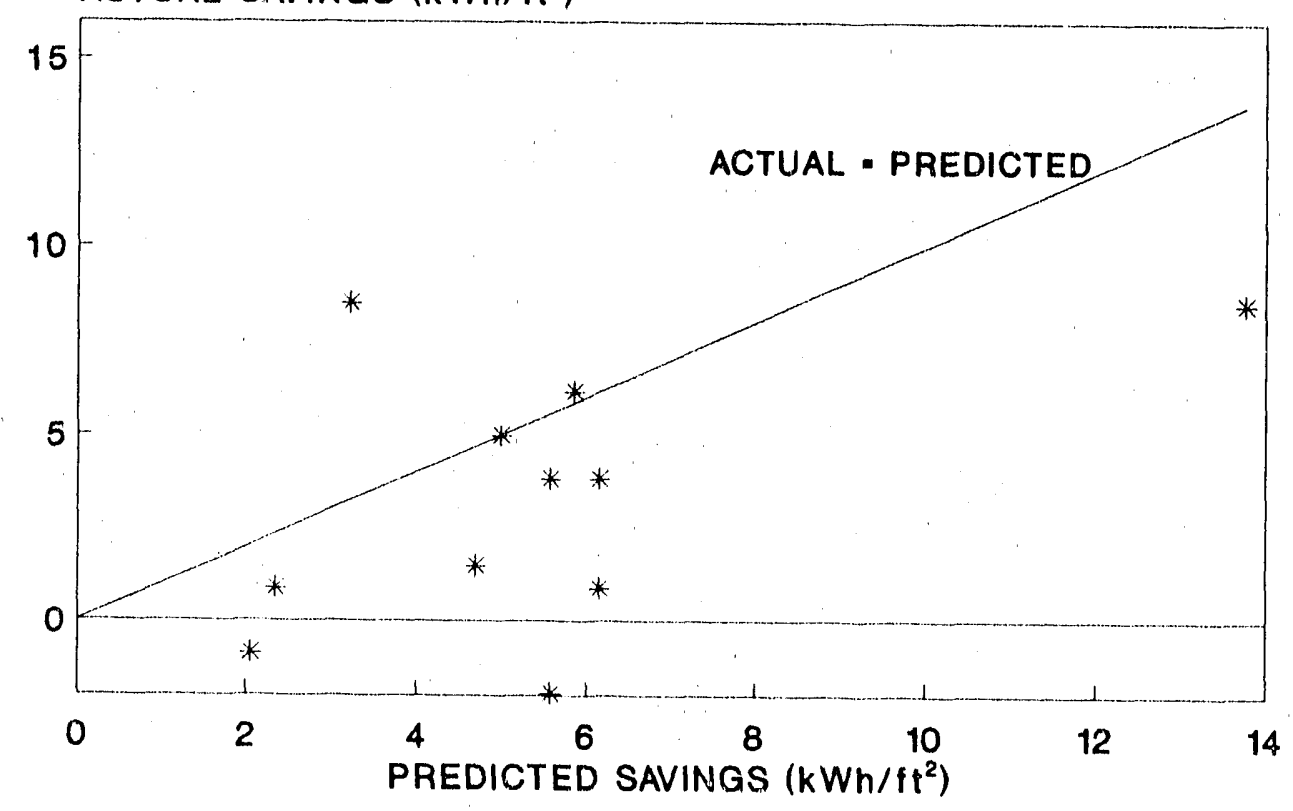

Fig. 10. Comparison of actual and predicted electricity savings for retrofits of commercial buildings (Greely, Harris, and Hatcher 1989). 
Table 5. Sample of demand-reduction adjustment factors used by New England Electric in its DSM bidding program

\begin{tabular}{llcc}
\hline Energy-efficiency & \multicolumn{3}{c}{ Type of facility } \\
\cline { 3 - 4 } action & I & II & III \\
\hline Lighting & & & \\
High-efficiency fluorescent lamps & 0.44 & 0.53 & 0.66 \\
High-efficiency ballasts & 0.52 & 0.70 & 1.00 \\
Interior-lighting occupancy sensors & 0.24 & 0.31 & 0.43 \\
Exit-sign-lighting conversion & 1.00 & 1.00 & 1.00 \\
& & & \\
Air conditioning & & 0.21 & 0.24 \\
High-efficiency air conditioners & 0.20 & 0.08 & 0.12 \\
Variable-air-volume system & 0.07 & 0.00 \\
\hline
\end{tabular}

aType I facilities include most retail and office buildings, which are occupied primarily during the day. Type II facilities are two-shift operations, such as manufacturers and warehouses. Type III faciities operate around the clock, including hospitals and three-shift manufacturers.

Source: Michaels (1988).

The next level of complexity uses monthly electricity bills for participating facilities. Typically, such records would be collected for at least a year before retrofit and a year after retrofit. For programs aimed at new construction, billing data would be collected for samples of new buildings that participated in the program and new buildings that did not. Analysis of the billing data might account for changes in winter and summer severity to correct for year-to-year variations in electricity use for space heating and air conditioning. If data on the facility, its operations, and its occupants are available, the analysis might also account for changes in hours of use, for changes in electricity-using equipment, and so on. This approach is well suited for residential and small commercial buildings, where the effects of outdoor temperatures are important determinants of electricity use. These effects can be captured with the use of well-known methods to adjust billing data for changes in heating degree days (Fels 1986).

If a program affects only some electricity end uses in a facility, it might not be possible to observe the savings at the whole-building level; the signal-to-noise ratio in monthly electricity bills may be too low to detect the savings. For example, water heating accounts for about $5 \%$ of the electricity use in a typical office building. Cutting electricity use for water heating by $20 \%$ will reduce total electricity use by only $1 \%$, a savings that could easily be overwhelmed by normal fluctuations in total electricity use. In such cases, end-use metering, while much more expensive than reliance on billing data, may be necessary to identify the actual savings. Such metering, because it records time-of-use (e.g., hourly) information is also important when the benefits of a program depend on the timing 
Table 6. Sample of methods used for verification of $\mathrm{kWh}$ savings in the Boston Edison Company ENCORE Program

Action

Convert incandescent

lights to fluorescont

lights

Resize pulleys and belts for HVAC fans, install energy-efficient motors, install HVAC controls, install occupancy sensors and efficient lamps

Install control system for chiller

Install variablefrequency drives on HVAC motors

Install system to control perimeter baseboard electric heating system

\section{Verification method}

1. Customer estimates number of hours that lights burn.

2. Contractor measures $\mathrm{kW}$-demand of random sample of lighting fixtures before retrofit.

3. Contractor similarly measures $k$ iv-dernand after retrofit.

4. $\mathrm{kW}$-demand/fixture multiplied by number of fixtures, both pre- and postretrofit.

5. Difference in $\mathrm{kW}$, pre- and post-retrofit, multiplied by number of burn hours to determine $\mathrm{kWh}$ savings/month.

1. Electricity use adjusted for number of days in billing cycle.

2. Electric space heating use adjusted on the basis of ratio of DD-historical period/DD-reference period, where DD refers to either heating or cooling degree days, both to base $65^{\circ} \mathrm{F}$.

3. Electricity use adjusted for changes in building use, both in conditioned floor area and hours of occupancy.

4. Electricity savings equals reference billing period consumption minus current billing period non-weather-sensitive $\mathrm{kWh}$ adjusted for changes in building use minus current billing period weather-sensitive $\mathrm{kWh}$ adjusted for changes in DD.

1. Pre-retrofit electricity use ( $\mathrm{kWh} / \mathrm{ton}$-hr) is computed, based on measurements of electricity use and of chilled water supply and return temperatures for at least 40 hours, and on manufacturer data on chilled water flow rate.

2. Similar measurements are made after retrofit.

3. Electricity savings equals difference in pre- and post-retrofit $\mathrm{kWh} / \mathrm{ton}$-hr times the base period ton-hr adjusted for any increases in ton-hr requirements.

1. Compute preretrofit electricity use ( $\mathrm{kWh} / \mathrm{month})$ by measuring electricity use for 8 hours for each unit, computing $\mathrm{kWh} / \mathrm{hr}$, and multiplying by the number of operating hours.

2. Similar measurements are made after retrofit.

3. Electricity savings equals difference in pre- and post-retrofit $\mathrm{kWh} / \mathrm{month}$ adjusted for any increase in operating hours.

1. Record $\mathrm{kW}$-demand of selected heating circuits at 30-minute intervals for 30 days.

2. Similar measurements are made after retrofit, also for 30 days.

3. HDD data are obtained for the two 30-day periods and for the 40-year average annual total.

4. Electricity savings equals $k W h / H D D$-pre minus $k W h / H D D-p o s t$, the difference multiplied by HDD-annual.

Source: Boston Edison Company (1989) 
of savings. For example, a winter-peaking utility will value a $\mathrm{kWh}$ saved on a January morning more than a $\mathrm{kWh}$ saved in spring, summer, or fall.

Load-research data collected by Florida Power \& Light (Sims 1990) documented the hour-by-hour demand reduction achieved by the large customers that participated in the company's load-control program (Fig. 11). These data formed the basis for the company's load-control tariff. Southern California Edison (1986) used end-use load data to determine the effects of different air-conditioner cycling strategies on demand reductions. Demand reductions for $100 \%$ cycling (four-hour shed) are roughly triple those achieved with $67 \%$ cycling (in which the units are turned off for $67 \%$ of the time during the control period), probably because of the natural duty cycle of the units. Also, the amount of load relief varies directly with outdoor temperature (Fig. 12).

\section{ANALYTICAL APPROACKIES}

The methods used to analyze energy savings vary. Engineering estimates of energy savings can be based on simple rules of thumb, on hand calculations, or on detailed engineering simulations that require considerable site-specific data.

Analysis of monthly electricity bills can include only simple adjustment for differences in heating degree days defined with a fixed balance point (e.g., $65^{\circ} \mathrm{F}$ ). Alternatively, the weather adjustment can allow for differences across customers in the balance-point temperature. Conditional demand analysis adjusts for differences across customers and time in winter and summer temperatures and in the structural characteristics of the facility and the econornic and demographic characteristics of the facility occupants (Parti and Parti 1980; Train and Ignelzi 1987). End-use load data can be adjusted only for weather or analyzed with regression approaches to account for various factors affecting electricity use (Caves, Lowry, and Wharton 1989).

Other analytical issues need to be considered in the definition of energy savings from DSM programs. Data users and providers need to agree on the point in the electric system at which savings are measured. The New England Power Pool (NEPOOL 1989) collects electricity-saving estimates "at the customer (meter) level;" these estimates, therefore, do not include transmission and distribution system losses nor do they include reserve margins. Identification of the long-term savings caused by DSM programs (see Fig. 8) may require additional data collection and analysis on the lifetime of the systems installed, their degradation with time, and the energy-related behaviors of facility operators. Finally, data on the electricity savings associated with certain technologies (and perhaps some programs) may be transferable from one utility to another. The cost savings associated with such data transfers are likely to be large where end-use load-monitoring data are involved. 


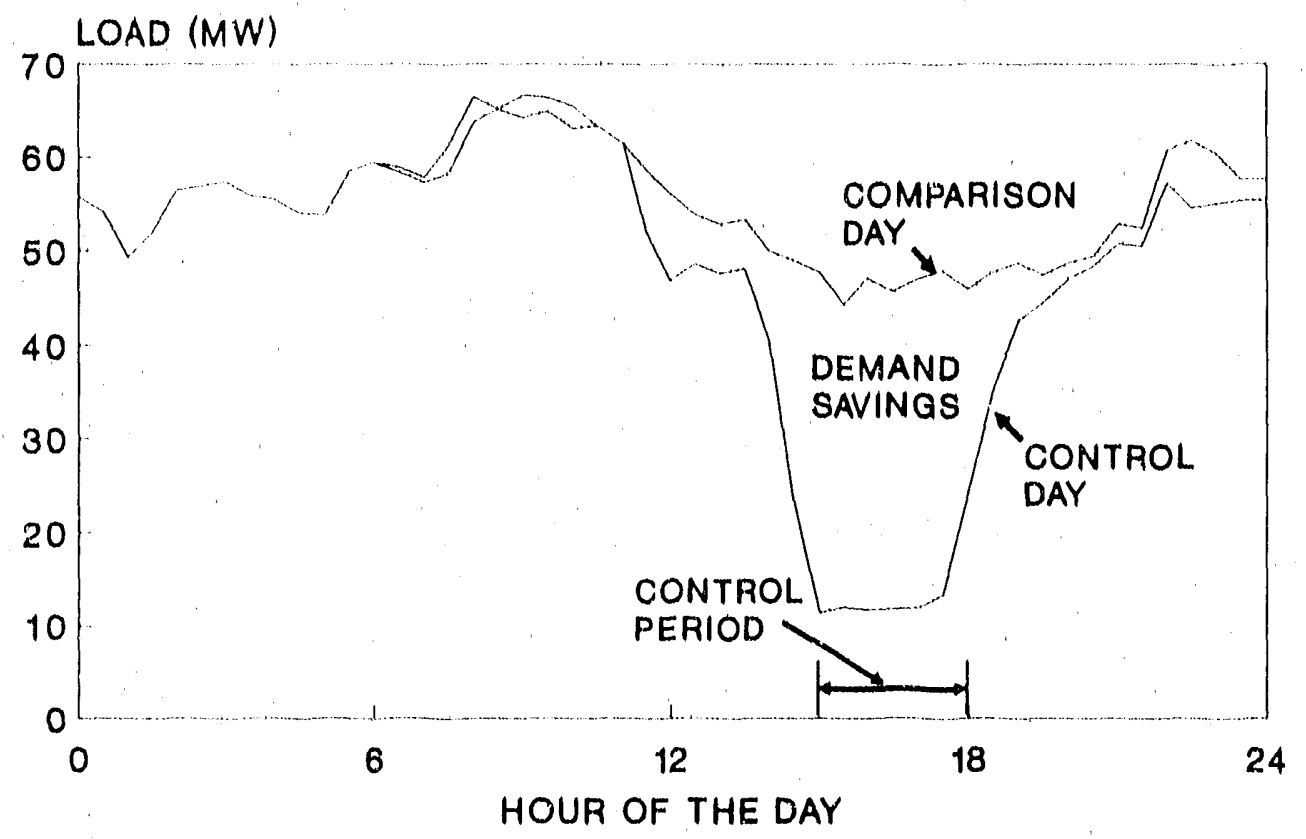

Fig. 11. Load relief achieved by large commercial and industrial customers participating in Florida Power \& Light's load-control program. These 12 customers cut demand by 36 MW in June 1989.

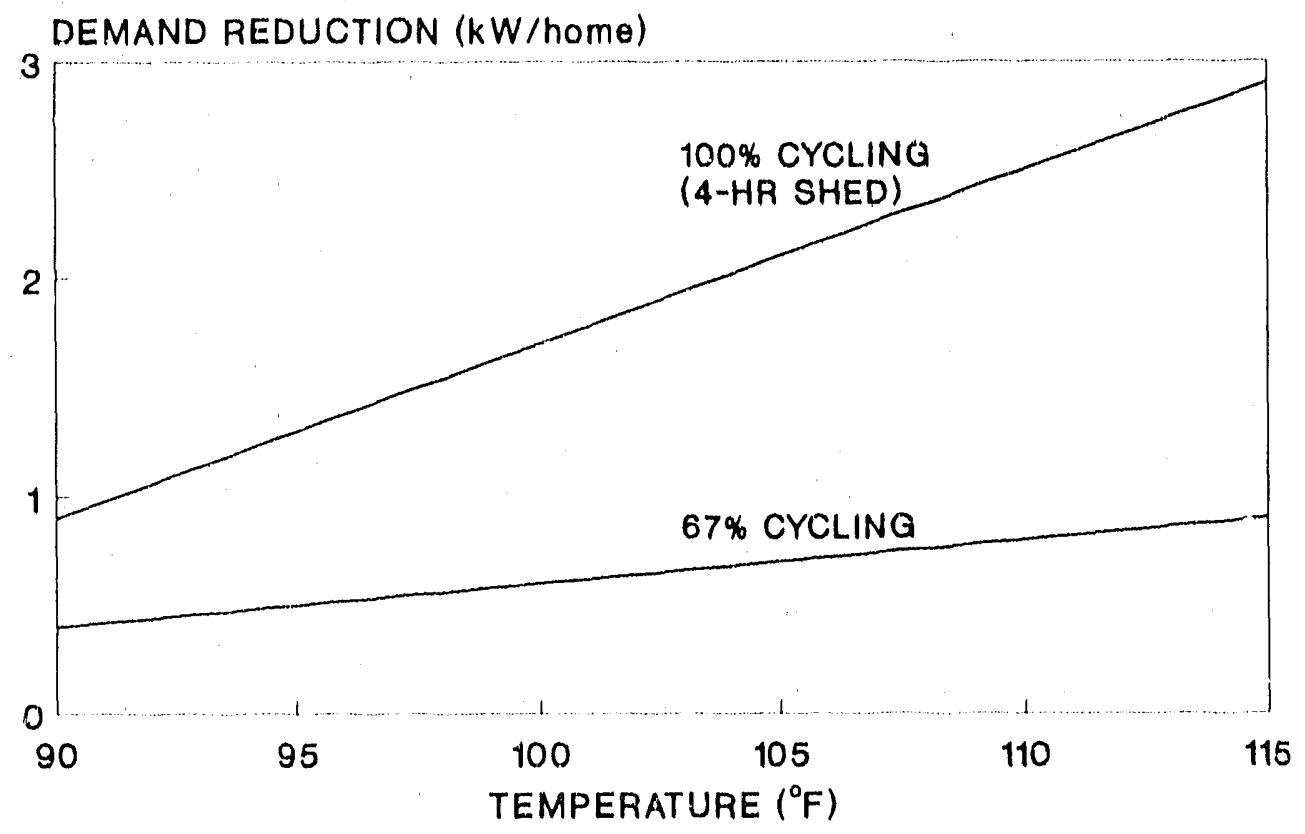

Fig. 12. Load reductions obtained by Southern California Edison through residential air-conditioner control as functions of cycling strategy and outdoor temperature. 


\section{DSM-PROGRAM COSTS ${ }^{*}$}

\section{COST COMPONENTS}

Definitions of program costs can include all costs, both those borne by participating custorners as well as those borne by the utility, or include utility costs only. Sometimes, costs refer only to the direct costs of the devices and their installation. And sometimes, costs include not only the direct costs but also the administrative activities (e.g., staff training, $\therefore$ dvertising, quality control, equipment, and program evaluation) plus corporate overhead. Occasionally, costs are divided into fixed and variable elements and sometimes into startup and steady-state components. Clearly, there are different elements associated with DSM program costs and different ways to define these elements. Therefore, the total cost per $\mathrm{kWh}$ saved (or per $\mathrm{kW}$ reduction in demand) may reflect different contributions from customers and utilities (Fig. 13).

The California Public Utilities Commission and Energy Commission (1987) defined several perspectives from which the benefits and costs of DSM programs can be assessed. The key perspectives include participants, nonparticipants (ratepayer impact test), the utility (revenue requirements), and society (total resource cost test). Each test considers different cost components.

Berry (1989) reviewed cost data and data definitions from several utilities. She found general consistency in definitions of administrative and direct costs. For example, the utilities usually defined labor costs, advertising, and travel as administrative costs. They also considered incentive payments to customers (such as rebates or loans) to be direct (nonadministrative) costs. While the broad categories of administrative and direct costs were similar among utilities, the number and type of specific cost components varied.

Generic program cost categories, based on the definitions developed for NORDAX, are shown in Table 7. The NORDAX classification treats incentive payments quite differently than most utilities do. NORDAX considers incentive payments variable marketing costs, while most utilities consider incentives to be direct costs.

Program costs also vary with time, by the stage of program development, the technologies promoted, the extent of program marketing and financial incentives offered, the desired level of market penetration, and the market segment to which the program is aimed. For example, the relationship between administrative and direct costs changed over time for

"Much of the material in this chapter is from Berry (1989). 
Puget Power's commercial sector programs (Berry 1989). As these programs matured, their administrative costs declined (Fig. 14).

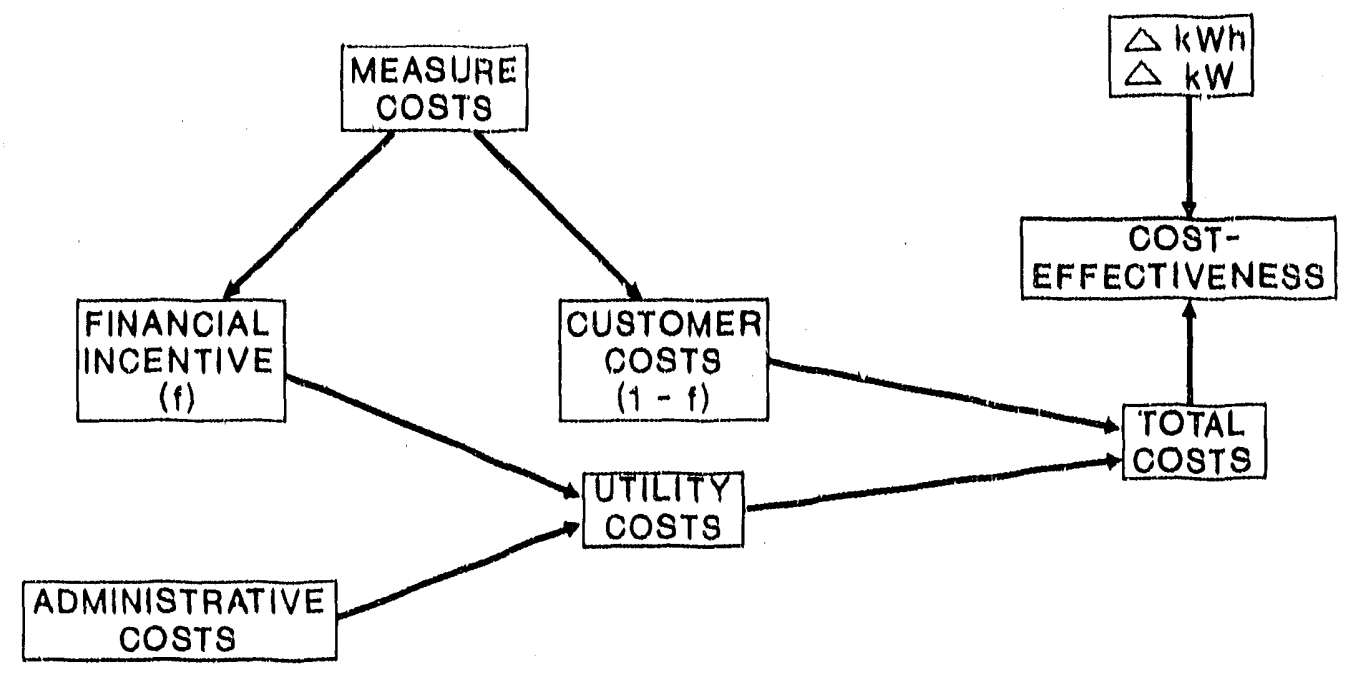

Fig. 13. Total program costs may be distributed in a variety of ways. (The fraction of the installation cost paid by the utility is $\mathrm{f}$.)

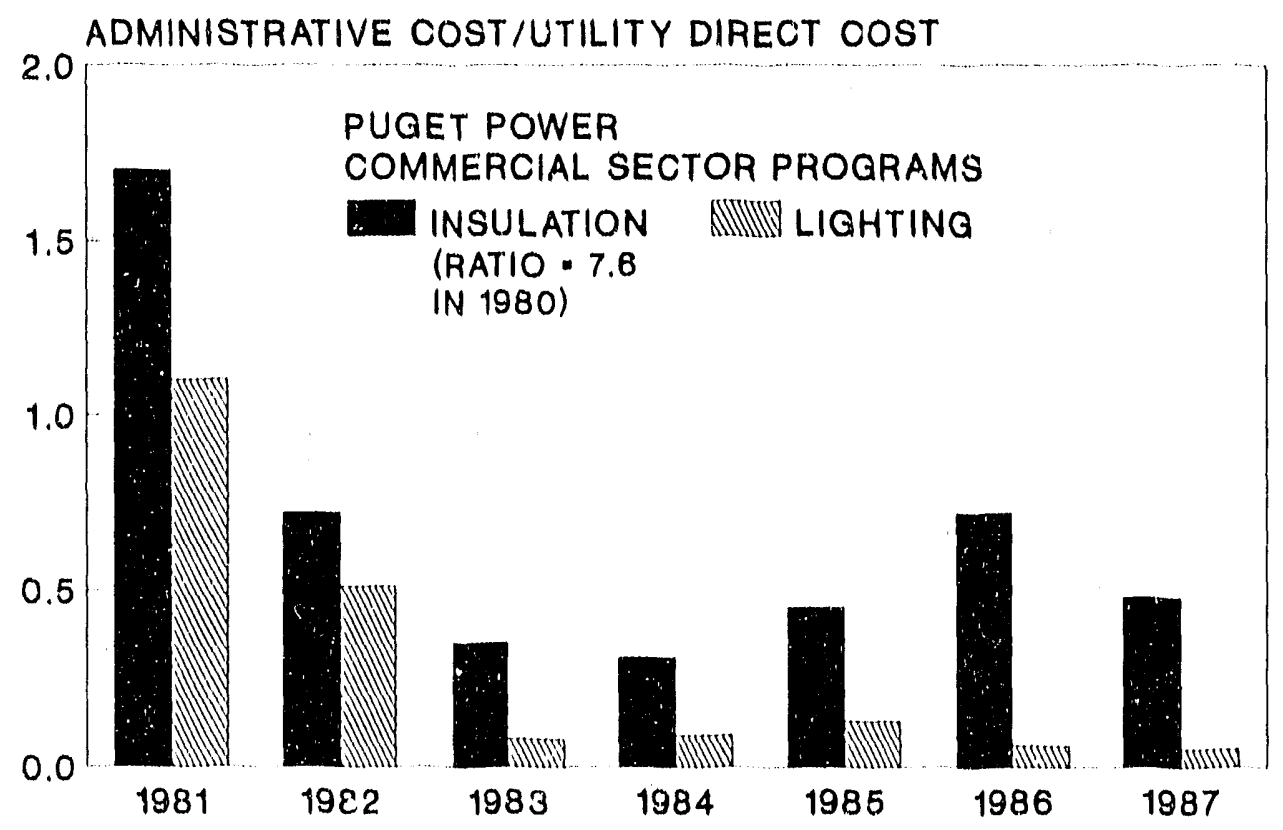

Fig. 14. Ratio of administrative costs to utility direct costs for two Puget Power programs for commercial customers. 


\section{Table 7. Definitions of direct and administrative program cost categories}

Direct costs:" Payments to contractors that install devices, financial incentives given to participating customers, and other costs for the purchase and installation of DSMprogram equipment and systems.

Development Costs: The market research, load research, creation of the program concept, and staff development and training associated with preparing a new program.

Administrative Fixed Costs: The program management, including labor, equipment, and material, that does not depend on the number of participants.

Administrative Variable Costs: The program management that varies directly with the number of participants. (For example, in an audit program, the time to conduct an audit is considered variable.)

Fixed Marketing Costs: The program promotion, including staff time to prepare and implement promotional strategies, that does not vary with the number of participants.

Variable Marketing Costs: ${ }^{b}$ The program promotion that fluctuates with the level of participation generated.

a Direct costs may include the customer payment for the DSM actions.

${ }^{b}$ The NORDAX definition includes incentives paid to participants as a variable marketing cost rather than a direct cost.

Sources: NORDAX (1989) and Berry (1989).

\section{ADMINISTRATIVE COSTS}

The definition of administrative costs is especially problematic and shows the most variation across utilities. These costs can be substantial and in some cases can exceed direct costs. Administrative costs support a variety of functions including (1) program planning, design, analysis, and evaluation; (2) activities designed to reach customers, bring them into the program, and deliver services to them (e.g., marketing, audits, application processing, and hid reviews); (3) post-installation inspections and other types of quality control; (4) staff recruitment, placement, development, and training; (5) data collection, recordkeeping, reporting, and accounting; and (6) overhead costs, such as office space and equipment, vehicles, insurance, and legal fees.

A program with lower administrative costs is not necessarily more efficient or effective, and the proportion of total costs spent on administration is clearly not the same for all programs. Consider a $100 \%$ rebate program that has no advertising, no quality control, and relies on participants to certify that they installed appropriate equipment. Such a program has very low administrative costs (especially compared to the utility's total cost), 
but may have poor participation and low energy savings per total investment. Alternatively, a program may conduct market research that leads to effective, carefully targeted advertising. This program offers no financial incentive but substantial onsite assistance. The program has very high administrative costs, but may yield high participation rates and high savings per total investment.

\section{NORMALIZATION F'ACTORS}

To be useful, administrative costs must be adjusted by some factor that scales them to the program and allows for comparisons across programs. Typically, utilities compute the ratio of administrative expenditures to the utility's direct costs. Because the utility incentives usually do not cover the entire installed cost and the customer's contribution is rarely recorded, ratios of administrative costs to direct costs will vary with the size of the incentive. Therefore, programs with large incentives will, by simple arithmetic, have a lower ratio of administrative to direct costs.

In the start-up phase of a program, all costs may be administrative. Ratios above one may occur when only a few installations are made because direct costs are small compared to indirect costs. For some programs, such as those that provide only information, all utility costs are administrative.

Several ways to normalize administrative costs have different advantages and disadvantages (Table 8). An administrative cost ratio may be obtained by dividing the program's administrative costs by the utility's contribution to the installed costs. Alternatively, the divisor may include customer and utility costs, reflecting a societal rather than a utility perspective. Some programs define administrative costs as the cost per customer contacted or per building audited or per building retrofit. Each of these methods of normalization can be useful, depending on the purpose of the analysis. Comparisons across programs on costs per participant, fur example, might suggest ways of lowering these costs. Analysis of cost effectiveness would use different methods depending on the perspective being considered.

Although $\mathrm{kWh}$ saved is not generally used to normalize administrative costs, this approach would be the most useful one for planning purposes. Direct costs are already related to the expected electricity savings in conservation-supply curves. If administrative costs also could be normalized by electricity savings, they could be combined with direct costs to estimate the total cost per $\mathrm{kWh}$ saved. Current planning approaches often assume that administrative costs add a fixed ratio of expenses to the direct costs in all cases. In reality, the administrative cost of achieving a desired level of electricity savings will vary by program type and by the required level of market penetration. 
Table 8. Alternative ways to normalize administrative costs

\begin{tabular}{|c|c|c|}
\hline Definition & Advantages & Disadvantages \\
\hline $\begin{array}{l}\text { Indirect costs } \\
\text { incurred by utility }\end{array}$ & \multirow{2}{*}{$\begin{array}{l}\text { Requires no new data } \\
\text { collection; utilities already } \\
\text { track their expenses in this } \\
\text { format. Useful for planning } \\
\text { budgets for future programs. } \\
\text { Useful to compute utility } \\
\text { recovery of program costs. }\end{array}$} & \multirow{2}{*}{$\begin{array}{l}\text { Hard to compare results } \\
\text { across programs and utilities. } \\
\text { Difficult to interpret meaning } \\
\text { of ratios because they are } \\
\text { affected by the size of the } \\
\text { utility incentive. }\end{array}$} \\
\hline $\begin{array}{l}\text { Installation costs } \\
\text { incurred by utility }\end{array}$ & & \\
\hline All indirect costs & \multirow{2}{*}{$\begin{array}{l}\text { Allows for comparability } \\
\text { across programs and utilities. } \\
\text { Appropriate for computing } \\
\text { societal cost effectiveness. }\end{array}$} & \multirow{2}{*}{$\begin{array}{l}\text { Requires additional data } \\
\text { collection. May be difficult } \\
\text { to collect the additional data. }\end{array}$} \\
\hline All direct costs & & \\
\hline $\begin{array}{l}\text { Indirect costs } \\
\text { incurred by utility }\end{array}$ & \multirow{2}{*}{$\begin{array}{l}\text { Useful for budget planning. } \\
\text { Simple formula for } \\
\text { reimbursement of } \\
\text { administrative costs. } \\
\text { Data are readily available. }\end{array}$} & \multirow[t]{2}{*}{$\begin{array}{l}\text { No information on direct } \\
\text { costs or on electricity savings. }\end{array}$} \\
\hline $\begin{array}{l}\text { Number of } \\
\text { participating } \\
\text { customers }\end{array}$ & & \\
\hline Indirect costs & \multirow{2}{*}{$\begin{array}{l}\text { Reflects goal of reducing } \\
\text { demand at the lowest cost. } \\
\text { Could be combined with data } \\
\text { on direct costs. }\end{array}$} & \multirow{2}{*}{$\begin{array}{l}\text { Definition of savings must be } \\
\text { clear and consistent for } \\
\text { results to be comparable. } \\
\text { Need to address net ys total } \\
\text { savings, predicted vs actual } \\
\text { savings, free riders, etc. }\end{array}$} \\
\hline Electricity savings & & \\
\hline
\end{tabular}

The trade-offs between the administrative and direct costs borne by utilities are important. As the utility contribution to direct costs increases, the administrative costs often decrease. In some cases, paying $100 \%$ of the installation costs reduces the administrative costs enough to make the tota! cost per $\mathrm{kWh}$ saved less than it would be at lower incentive levels.

An experiment conducted by Niagara Mohawk Power Company, for example, compared the electricity savings resulting from a free offer of low-cost electric water heater measures with those of half-price and shared-savings offers (Fig. 15). Savings produced by the free offer were much higher (at a per $\mathrm{kWh}$ cost much less) than savings from either the half-price or the shared-savings offers (Flaim, Miedema, and Clayton 1989). Another utility's promotional and advertising costs for an insulation program for low-income housing were 
greater than the costs for free installation by the utility (Condelli et al. 1984), These examples show that designing cost-effective programs requires an understanding of how to minimize total costs while achieving the desired levels of participation and electricity savings. More data on the trade-offs between the administrative and direct costs per $\mathrm{kWh}$ saved would help planners to achieve this goal.

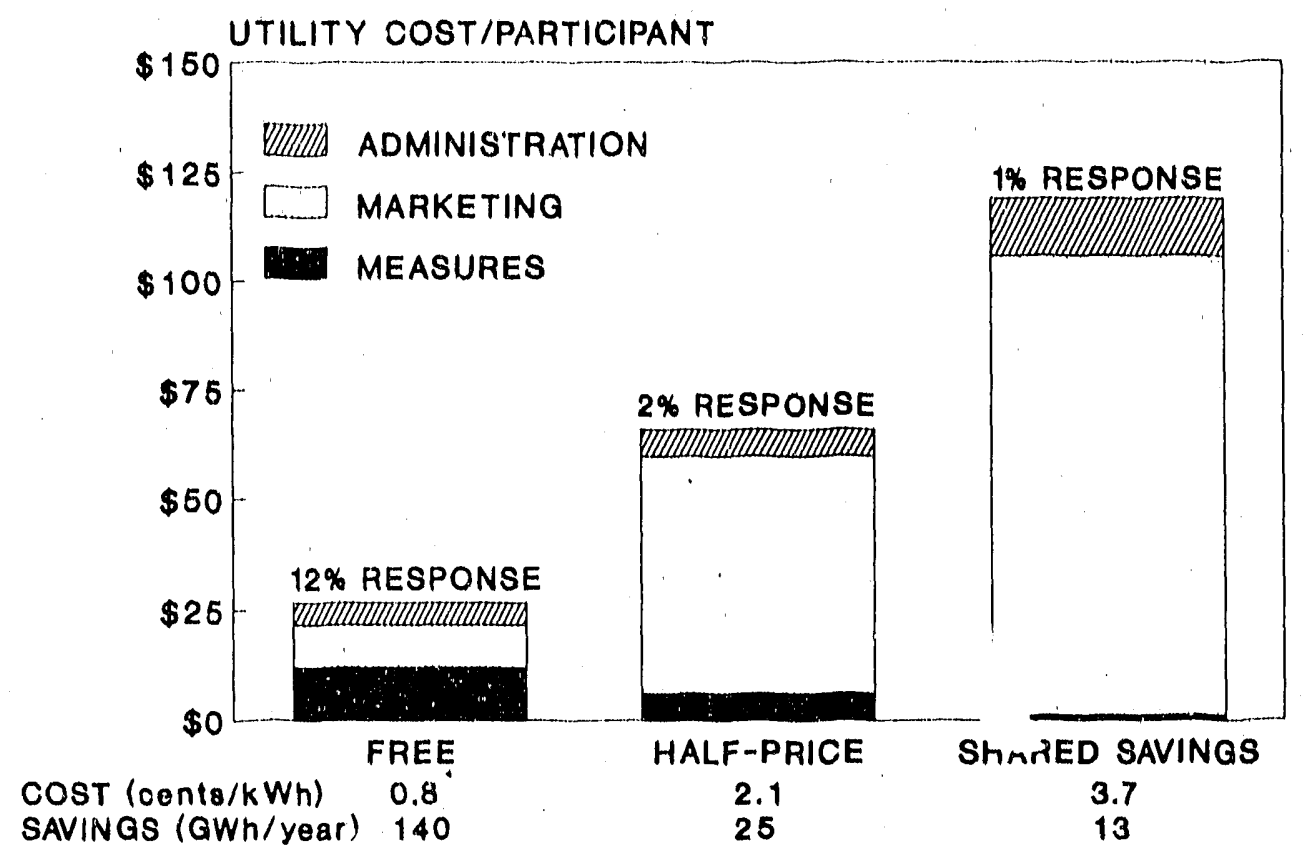

Fig. 15. Comparison of costs to Niagara Moliawk for low-cost measures offered free, at half price, and through a shared-savings program. 


\section{RECENT EFFORTS TO COLLECT DSM-PROGRAM DATA}

During the past several years, a few PUCs (including California, Maine, Massachusetts, and New York) have worked with their utilities to develop standard forms for reporting the costs and effects of DSM programs (Table 9). These forms help improve program management, sharpen estimates of program cost effectiveness, and enhance PUC oversight of the programs (Bergeron and Parker 1989). EIA (1989b) recently added a few questions on DSM programs to its Annual Electric Utility Report, Form EIA-861. NORDAX (1989), as mentioned earlier, collects DSM-program data for its members. NEPOOL (1989) uses a variation of the NORDAX instrument to collect estimates of the future effects of utility DSM programs. And EPRI (1989a and b) periodically surveys utilities to identify the number and types of DSM programs they operate.

These data-collection documents differ in many ways. The EIA, Massachusetts, NEPOOL, and New York forms, for example, collect estimates of future electricity savings and program costs, while the ether forms collect data on past program performance.

None of these forms adequately considers the difference between net and total savings. The Massachusetts form is confusing because it requests information on program savings that are "net of other, non-program related impacts" but then says that such "savings estimates should not subtract savings resulting from free riders." The NORDAX instrument requests estimates of the percentage of program participants that are free riders but does not make clear whether, or how, these estimates are used to compute energy savings. The other forms do not mention net vs total savings.

The NORDAX form is especially detailed about program markets, the customers and end uses to which each program is addressed, the base and new technologies addressed by the program, and other aspects of program design and implementation. The EIA form is the least detailed, probably because it collects aggregate data from all utilities in the U.S. As such, it requires only utility-level information on energy savings and load reductions and on program costs. Questions ask for estimated reductions in peak demand and in annual electricity use caused by the utility's DSM programs and for capital expenditures and operating costs for these programs. This information is requested for the current year and for each of the following ten years.

Some forms include narratives that define the terms. The NORDAX forms contain detailed descriptions for most of the data elements. An Appendix to the NORDAX form provides a numbering system for individual technologies organized by customer class, end use, and equipment size. For example, the Appendix lists 21 sizes and types of residential central air conditioners. 
Table 9. Comparison of recent efforts to collect DSM-program data

\begin{tabular}{|c|c|c|c|c|c|c|}
\hline Data element & $\mathrm{CA}$ & ME & MA & NY & NORDAX & EIA \\
\hline \multicolumn{7}{|l|}{ Time period(s) covered } \\
\hline \multicolumn{7}{|l|}{ Historical } \\
\hline Annual & $\mathrm{X}$ & $\mathrm{X}$ & $\mathrm{X}$ & $\mathrm{X}$ & $\mathbf{X}$ & \\
\hline Cumulative & & $\mathbf{X}$ & $\mathbf{X}$ & & $\mathbf{X}$ & \\
\hline Future & & & $\mathrm{X}$ & $\mathbf{X}$ & 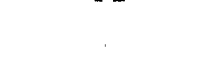 & $\mathrm{X}$ \\
\hline \multicolumn{7}{|l|}{ Program effects } \\
\hline \multicolumn{7}{|l|}{ Energy savings (MW and GWh) } \\
\hline Net & $\mathrm{X}$ & & ? & & ? & \\
\hline Total & $\mathrm{X}$ & $\mathrm{X}$ & $?$ & $\mathrm{X}$ & $\mathbf{X}$ & $?$ \\
\hline Number of participants & $?$ & $\mathrm{X}$ & $\mathrm{X}$ & $\mathrm{X}$ & $\mathrm{X}$ & \\
\hline Number of eligible customers & & & $\mathrm{X}$ & $\mathrm{X}$ & $\mathrm{X}$ & \\
\hline $\begin{array}{l}\text { Number of technology (end-use) } \\
\text { units installed }\end{array}$ & $\mathrm{X}$ & $\mathrm{X}$ & & & $\mathbf{X}$ & \\
\hline Details on utility costs & & $\mathrm{X}$ & & $\mathrm{X}$ & $\mathrm{X}$ & \\
\hline Customer costs & $\mathrm{X}$ & $\mathrm{X}$ & $\mathrm{X}$ & & $\mathrm{X}$ & \\
\hline Cost-effectiveness tests & $\mathrm{X}$ & & & $\mathrm{X}$ & & \\
\hline \multicolumn{7}{|l|}{ Program characteristics } \\
\hline Type (e.g., load-shape objective) & $\mathrm{X}$ & $\mathrm{X}$ & & $?$ & $\mathrm{X}$ & \\
\hline $\begin{array}{l}\text { Services provided (e.g., } \\
\text { information, incentives) }\end{array}$ & $?$ & & $\mathrm{X}$ & $?$ & $\mathbf{X}$ & \\
\hline \multicolumn{7}{|l|}{ Program participation } \\
\hline Customer class & $\mathrm{X}$ & ? & $\mathrm{X}$ & & $\mathrm{X}$ & \\
\hline Building type or SIC code & $\mathrm{X}$ & $?$ & $\mathrm{X}$ & & $\mathrm{X}$ & \\
\hline End use & $X$ & $\mathrm{X}$ & $\mathrm{X}$ & $\mathrm{X}$ & $X$ & \\
\hline Marketing methods used & $?$ & & $\mathrm{X}$ & $\mathrm{X}$ & $\mathrm{X}$ & \\
\hline
\end{tabular}

${ }^{a}$ An $\mathrm{X}$ means that the data-collection form includes this element, a blank space means that the form does not include the element, and a ? means that this element is included but its definition is not clear.

Sources: California PUC (1989), Maine PUC (1988), Massachusetts Department of Public Utilities (1989), New York Department of Public Service (1990), NORDAX (1989), and EIA (1989b).

The California form defines seven types of DSM programs: conservation, load management, fuel substitution, load retention, load building, measurement and evaluation, and other. Data on annual program costs, energy savings (in $\mathrm{MWh}$ ), and capacity reductions 
(in MW) are collected for each type of program, by customer class, and by type of service delivered to customers (Table 10).

For some program types, the California PUC requires additional detail on building type and end use (e.g., space heating in single-family homes or air conditioning in office buildings). Additional detail for individual technologies is required for programs that offer financial incentives to customers. The Massachusetts form is the most detailed in its breakdown of customers by building type and SIC code.

The Massachusetts and New York forms request information on the potential for future electricity savings and peak-load reductions. While Massachusetts requests estimates of the full technical potential, New York asks for estimates of the economic and achievable potentials. Both forms request this information by building type. The New York form also asks for the information by end use.

These data-collection instruments could form the basis for a uniform set of questions on utility DSM programs. Development of such questions and their associated definitions could be done with staff from electric utilities, PUCs, and DOE (FERC, EIA and the Office of Conservation and Renewable Energy). 
Table 10. DSM program categories defined by the California Public Utilities Commission (1989)

\begin{tabular}{ll}
\hline CONSERVATION & LOAD MANAGEMENT \\
Residential & Residential \\
Information programs & Air-conditioner cycling \\
Energy management services & Time-of-use rates \\
Weatherization retrofit incentives & Pool pump timer \\
New construction & Other \\
Appliance efficiency incentives & Nonresidential \\
Direct assistance & Air-conditioner cycling \\
Master meter & Interruptible rates \\
Other & Time-of-use rates \\
Nonresidential & Thermal energy storage \\
Information programs & Other \\
Energy management services & \\
Commercial & \\
Industrial & FUEL SUBSTITUTION \\
Agricultural & Residential \\
Energy management incentives & Nonresidential \\
Commercial & \\
Industrial & LOAD BUILDING (and RETENTION) \\
Agricultural & Residential \\
New construction & Nonresidential \\
Street Lighting & \\
Other & MEASUREMENT AND EVALUATION \\
System efficiency & Load metering \\
Conservation voltage reduction & Customer surveys \\
Other & New-technology assessments \\
& Other \\
\hline
\end{tabular}

${ }^{\mathrm{a}}$ These classes are split further into large and medium/small. 


\section{FUTURE ACTIONS AND CONCLUSIONS}

Accurate and credible data on utility DSM programs are needed for planning programs that can replace some power plants, for PUC regulatory reforms that reward utilities for implementation of successful DSM programs, and for including DSM resources in competitive auctions for new power supplies. Several approaches are possible to improve the amount, quality, and accessibility of DSM-program data.

\section{FUTURE ACTIONS}

This section outlines one method to develop definitions and common reporting formats for DSM programs. The proposed strategy recognizes the different data needs of utilities, state regulators, and federal policy makers. In particular, data needs are likely to be less detailed in going from utilities to PUCs to the Federal Government.

1. Organize a group to develop proposed data-collection instruments on utility DSM programs. The group should include utility DSM and system planners; PUC staff; representatives from industry groups such as EPRI, EEI, the National Rural Electric Cooperative Association, and the American Public Power Association; representatives from the Energy Conservation Committee of the National Association of Regulatory Utility Commissioners; and DOE.

2. Discuss and agree on the key data elements that characterize DSM programs (Table 11). Priorities should be developed among these variables (recognizing differences among data elements in the cost of acquisition and value to different groups). Because data are needed at both the program-specific level and the utility level, methods of aggregating data (e.g., from individual programs to customer classes) need to be developed.

3. Develop consensus definitions for key data elements. More than one definition may be acceptable as long as the user states which definition is being used. The standards developed by IEEE and the power-supply definitions produced by EEI and Pacific Gas and Electric provide models for these DSM definitions. The output from this task could be a handbook that explains how to define, collect, manage, analyze, and report data on DSM programs. The definitions should recognize differences among estimates in quality and cost (e.g., engineering estimates of electricity savings vs estimates based on end-use load-research data). 
4. Prepare forms that utilities could use to collect and report data to PUCs and to EIA and FERC (e.g., modifications to FERC Form 1 and to EIA-861). A key part of this task is understanding the processes that lead to changes in EIA and FERC forms.

5. Test these data-collection instruments with a few utilities and other data users to ensure that completing the forms is feasible, that the responses are accurate, and that the information provided is useful.

6. Use these forms for program and resource planning and for reporting information to state and federal governments.

The actual process followed in developing definitions and reporting formats will be more complicated and iterative than the one outlined above. However, developing consensus on the key data elements and their definitions should begin now.

Table 11. DSM-program data elements for which definitions are needed

Program participation

Annual vs cumulative

Participant

Eligible nonparticipant, accounting for attrition and for past participation

Replacement, new construction, and retrofit markets

Electricity savings

Total vs net savings

Energy savings, peak demand reductions, and load-shape changes

Durability of savings

Measurement methods: engineering estimates, ad hoc measurements, electricity bills, end-use load data

Program costs

Customer plus utility

Direct plus administrative

Startup vs steady-state

Fixed vs variable

\section{CONCLUSIONS}

Electric utilities spent more than $\$ 1.2$ billion on DSM programs in 1989 , and this amount will surely increase during the 1990s. The substantial disparities across utilities (and even across programs within utilities) in how data are defined, collected, analyzed, and reported makes it difficult to determine the energy and peak-demand savings and the cost 
effectiveness of these programs. For DSM programs to serve as valuable energy and capacity resources, we need better data on program costs and performance. In addition, such data are needed to reduce the serious imbalance that exists between the amount, quality, and relevance of data on electricity supply on the one hand and on utility DSM programs on the other. Without more information on DSM programs, utilities and regulators will find it difficult to choose among competing demand and supply alternatives.

Fully integrating DSM programs into a utility's resource portfolio requires three types of information: (1) baseline data on existing patterns, trends, and determinants of electricity use; (2) engineering data on the costs and performance of energy-efficiency and loadmanagement technologies; and (3) data on the participation in, electricity savings caused by, and costs of utility DSM programs (Hirst and Goldman 1990). This report focuses on the third topic because information on DSM programs is both limited and crucial.

If accurate and consistent data on utility DSM programs were available, utilities that run exemplary DSM programs would be recognized, much as utilities are recognized for operating power plants with high capacity factors and low heat rates. The Wolf Creek nuclear plant in Kansas "headed the list of U.S. nuclear and fossil-fueled plants in reliability and power production for 1989" (Public Utilities Fortnightly 1990) because it ran continuously for 331 days. Possible metrics for assessing the value of DSM programs include:

\footnotetext{
- Energy savings (GWh) as a percent of annual sales

- Peak reduction (MW) as a percent of system peak demand

- DSM expenditures per $\mathrm{kW}$ or per $\mathrm{kWh}$ saved.
}

Treating demand and supply resources consistently requires much more information on DSM programs. Utilities, PUCs, and DOE should expand the scope of the datacollection forms completed by utilities to include information on such programs. Utilities would use these data for DSM-program design and operation, and for resource planning. PUCs would use such data to assess utility progress in meeting their DSM goals and as the basis for providing financial incentives for successful DSM programs. And DOE would use these data in developing the National Energy Strategy and other policy, program, and R\&D activities. 


\section{ACKNOWLEDGMENTS}

I thank Linda Berry for her advice throughout the course of this project, I thank Denis Bergeron, Linda Berry, William Booth, Cheryl Carlson, Tom Foley, Philip Hanser, Jeffrey Harris, Elizabeth Hicks, Mary Hutzler, Craig Kazin, Michael MacDonald, Richard Parker, Dan Quigley, Jonathan Raab, Deborah Ross, Don Schultz, Richard Spellman, Sam Swanson, Richard Tempchin, and Stephen Wiel for their helpful comments on a draft of this report. I appreciate the ongoing advice and encouragement from Jacob Kaminsky and Philip Hanser, the DOE and EPRI managers for this project, and from Sam Swanson of the NARUC Energy Conservation Committee. Finally, I thank Fred O'Hara for editing the report and Ethel Schorn for help in producing the graphs and assembling the final report. 


\section{REFERENCES}

H. R. Allen 1990, personal communication, Georgia Power Company, System Control Center, Atlanta, GA, March.

Argonne National Laboratory 1989, Enengy Program Evaluation: Conservation and Resource Management, Proceedings of the Fourth International Conference in Chicago, Argonne, IL, Augist.

D. P. Bergeron and R. B. Parker 1989, "How the Maine PUC Uses Standardized Utility Reports to Monitor Program Cost Effectiveness," Demand-Side Management: Partnerships in Planning for the Next Decade, Proceedings of the ECNE National Conference on Utility DSM Programs, EPRI CU-6598, Electric Power Research Institute, Palo Alto, CA, November.

L. Berry 1989, The Administrative Costs of Energy Conservation Programs, ORNL/CON-294, Oak Ridge National Laboratory, Oak Ridge, TN, November.

L. Berry 1990, The Market Penetration of Enengy-Efficiency Programs, ORNL/CON-299, Oak Ridge National Laboratory, Oak Ridge, TN, April.

Boston Edison Company 1989, Status Report, Encore, Energy Conservation Retrofit Program, Boston, MA, March.

California Public Utilities Commission and California Energy Commission 1987, Economic Analysis of Demand-Side Management Programs, San Francisco and Sacramento, CA, December.

California Public Utilities Commission 1989, Demand-Side Management Reporting Requirements Manual, 3rd edition, San Francisco, CA, December.

D. W. Caves, M. N. Lowry, and J. B. Wharton 1989, "Evaluating Alternative Measures of Credited Load Relief: Results from a Recent Study for New England Electric," DemandSide Management: Partnerships in Planning for the Next Decade, Proceedings of the ECNE National Conference on Utility DSM Programs, EPRI CU-6598, Electric Power Research Institute, Palo Alto, CA, November.

Duke Power Company 1990, Lincoln Combustion Turbine Station, NCUC Rule R8-61(b) Information, filed with the North Carolina Utilities Commission, Charlotte, NC, February. 
Edison Electric Institute 1984, Glossary of Electric Utility Terms, Washington, DC.

Edison Electric Institute 1989a, Statistical Yearbook of the Electric Utility Industry/1988, Washington, DC, November.

Edison Electric Institute 1989b, EEI Power Statistics Data Base, Washington, DC.

Electric Power Research Institute 1986, TAG - Technical Assessment Guide, Volume 1: Electricity Supply-1986, EPRI P-4463-SR, Palo Alto, CA, December.

Electric Power Research Institute 1987, TAG - Technical Assessment Guide, Volume 3: Fundamentals and Methods, Supply, 1986, EPRI P-4463-SR, Palo Alto, CA, May.

Electric Power Research Institute 1989a, 1987 Survey of Commercial-Sector Demand-Side Management Programs, EPRI CU-6294, Palo Alto, CA, March.

Electric Power Research Institute 1989b, 1988 Survey of Residential-Sector Demand-Side Management Programs, EPRI CU-6546, Palo Alto, CA, October.

Energy Information Administration 1989a, Historical Plant Cost and Annual Production Expenses for Selected Electric Plants 1987, DOE/EIA-0455(87), U.S. Department of Energy, Washington, DC, May.

Energy Information Administration 1989b, Form EIA-861, innual Electric Utility Report 1989, U.S. Department of Energy, Washington, DC.

Energy Information Administration 1990, Directory of Energy Data Collection Forms, DOE/EIA-0249(89), U.S. Department of Energy, Washington, DC, January.

M. F. Fels, editor 1986, "Special Issue Devoted to Measuring Energy Savings: The Scorekeeping Approach," Energy and Buildings 9 (1 and 2), February/May.

Federal Energy Regulatory Commission 1988, FERC Form No, 1: Annual Report of Major Electric Utilities, Licensees and Others, U.S. Department of Energy, Washington, DC, December.

T. Flaim, A. K Miedema, and C. A. Clayton 1989, "The Impact of Financial Incentives on the Cost-Effectiveness of DSM Programs: Some Experimental Results," Demand-Side Management: Partnerships in Planning for the Next Decade, Proceedings of the ECNE National Conference on Utility DSM Programs, EPRI CU-6598, Electric Power Research Institute, Palo Alto, CA, November.

K. M. Greely, J. P. Harris, and A. M. Hatcher 1989, Measured Savings and Cost Effectiveness of Conservation Retrofits in Commercial Buildings, draft, LBL-27568, Lawrence Berkeley Laboratory, Berkeley, CA, October. 
E. Hirst 1987, "Planning Utility Demund-Side Programs: Deta and Analytical Needs," Electric Power Systems Research 12, 105.111.

E. Hirst 1990, "Balancing the Scales: Toward Parity in Electric Supply and Demand Data," The Electricity Joumal 3(4), 284.33, May.

E. Hirst et al. 1985, Actual Electricity Savings for Homes Retrofit by the BPA Residential Weatherization Program, ORNL/CON.185, Oak Ridge National Luboratory, Onk Ridge, TN, July.

E. Hirst and C. Goldman 199(), "Review of Demand-Side Data Needs for Least-Cost Utility Planning," Encrgy 15(5), 4(1)-411, May.

Institute of Electrical and Electronics Engineers 1987, IEEE Standard Definitions for Use in Reporting Electric Generating Unit Reliability, Availability, and Productivity, ANSI/LEEE Std 762-1987, New York, NY.

K. Keating 1988, editor, Program Evaluation, Proceedings of the 1988 ACEEE Summer Study on Energy Efficiency in Buildings, Vol. 9, American Council for an Energy-Efficient Economy, Washington, DC, August.

F. Krause, E. Vine, and S. Gandhi 1989, Program Experience and Its Regulatory Implications, A Case Study of Uitity Lighting Efficiency Programs, LBL-28268, Lawrence Berkeley Laboratory, Berkeley, CA.

J. M. Mac:Donald, T. R. Sharp, and M. B. Gettings 1989, A Protocol for Monitoring Energy Efficiency Improvements in Commercial and Related Buildings, ORNL/CON-291, Oak Ridge National Laboratory, Oak Ridge, TN, September.

Maine Public Utilities Commission 1988, Chapter 380 Quarterly Report, Augusta, ME.

Massachusetts Department of Public Utilities 1989, Filing Format for Annual C\&LM Reports, Boston, MA, August.

H. Michaels 1988, "Bulk Purchase of Conservation by Competitive Bid," Utility and Private Sector Conservation Programs, Proceedings of the 1988 ACEEE Summer Study on Energy Efficiency in Buildings, Vol. 6, 6.140-6.152, American Council for an Energy-Efficient Economy, Washington, DC, August.

S. Nadel 1990, Lessons Learned: A Review of Utility Experience with Conservation and Load Management Programs for Commercial and Industrial Customers, American Council for an Energy-Efficient Economy, Washington, DC, April.

New England Power Pool 1989, "NEPOOL DSM9() Data Collection Instrument," West Springfield, MA August. 
New York Department of Public Service 1990, Formats and Guidelines for July 2.3, 1990) DSM Plan Filing in Case 28223, Albany, NY, March.

North American Electric Reliability Council 1988, Generating Availability Report, 1983 - 1987, Princeton, NJ, September.

Northeast Region Demand-Side Management Data Exchange 1989, The Development of the Data Collection Instrument and the Data Collection Process, Edison Electric Institute, Washington, DC, June. See also Demand-Side Management Utility and Program Data Collection Sirrvey, an April 1989 revision of the Data Collection Instrument.

Northeast Region Demand-Side Management Data Exchange 1989, NORDAX: A Regional Demand-Side Management Database, Final Report, No. (77-89-32, Edison Electric Institute, Washington, DC, March.

Office of 'Technology Assessment 1989, Statistical Needs for a Changing U.S. Economy, OTABP-E-58, U.S. Congress, Washington, DC, September.

Pacific Gas and Electric 1985, Resource, An Encyclopedia of Utility Industry Terms, San Francisco, CA, January.

M. Parti and C. Parti 1980, "The Total and Applance Specific Conditional Demand for Electricity in the Household Sector," Bull Joumal of Economics 11(1), 309-321, Spring.

Public Utilities Fortnightly 1990, "Most Reliable U.S. Plant is in Burlington," Public Utilities Fortnightly 125(7), 39, March 29.

S. R. Sims 1990, personal communication, Load Management Department, Florida Power \& Light Company, Miami, FL, February.

Southern California Edison 1986, Residential Air Conditioner Cycling Program, Annual Report for 1985, Customer Service Department, Rosemead, CA, January.

K. E. Train and P. C. Ignelzi 1987, "The Economic Value of Energy-Saving Investments by Commercial and Industrial Firms," Energy 12(7), 543-553, July.

U.S. Department of Energy 1990, Interim Report National Enengy Strategy, DOE/S-0066P, Washington, DC, April. 

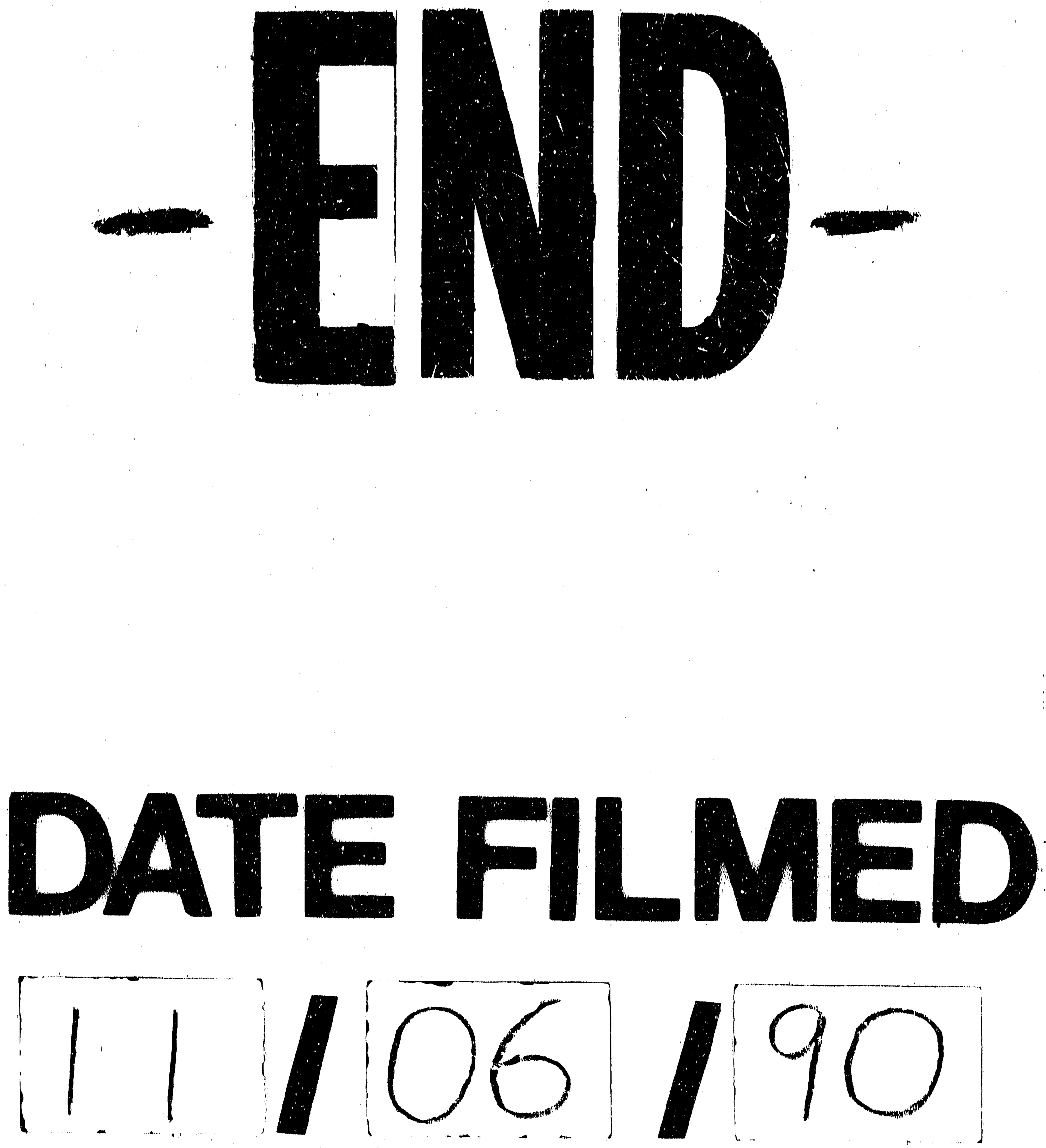
